Fort Hays State University

FHSU Scholars Repository

\title{
Hitler and Keitel: An Investigation of the Influence of Party Ideology on the High Command of the Armed Forces in Germany Between 1939 and 1945
}

Helmut J. Schmeller

Fort Hays State University

Follow this and additional works at: https://scholars.fhsu.edu/fort_hays_studies_series

Part of the History Commons

\section{Recommended Citation}

Schmeller, Helmut J., "Hitler and Keitel: An Investigation of the Influence of Party Ideology on the High Command of the Armed Forces in Germany Between 1939 and 1945" (1970). Fort Hays Studies Series. 41.

https://scholars.fhsu.edu/fort_hays_studies_series/41

This Book is brought to you for free and open access by the Forsyth Library at FHSU Scholars Repository. It has been accepted for inclusion in Fort Hays Studies Series by an authorized administrator of FHSU Scholars Repository. For more information, please contact ScholarsRepository@fhsu.edu. 

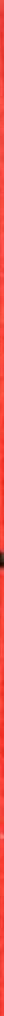

history series no. 7 june 1970

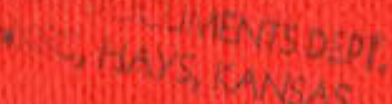

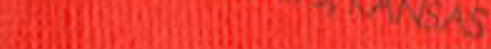




\section{Sclence Series}

\section{0}

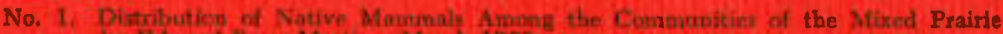
by Rdwand Petry Martin. March 1960.

\section{History Sories}

No. 1. Sin Martin-One Hundred Xears of Historiography, by Eutharino Ferris

\section{Economic Series}

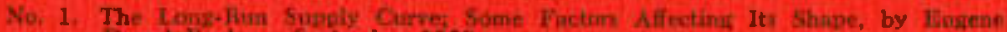
Burred Pinley. September 1960.

\section{Art Series}

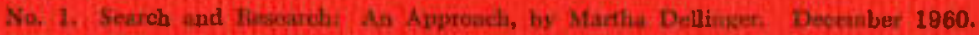

\section{Hitory Series}

\section{1}

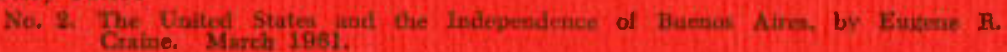

\section{Bibliography Series}

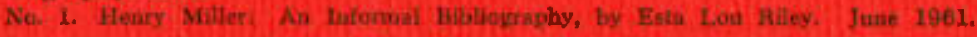

In 1981 two issues of the Fort Hays Studies-New Series were not issued but a history of the college was published.

Woatter, Laman Dwight. A History of Fot Huys Nanies State Cailage-1902-1961. $200 \mathrm{pi}$

Economics Serie:

\section{2}

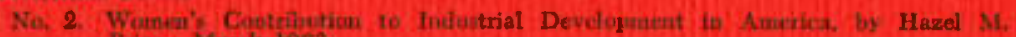
Pisce. Munda 1062.

\section{It terature Series}

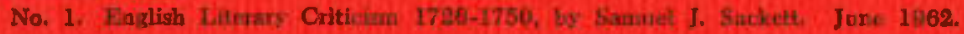

\section{Bibliography Séries}

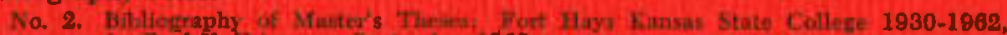
by Paul K. Pricener. Sejtânber 1962

\section{History Series}

No. 3. Frningt's Expedition Through Kansas, 1840-1854, by Lilbura H. Horton, Jr. Deoember 1962

\section{Science Series}

\section{4}

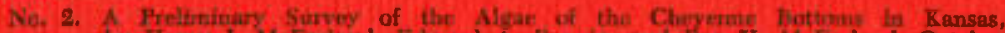

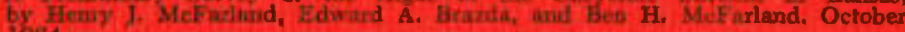
1984

\section{Literature Series}

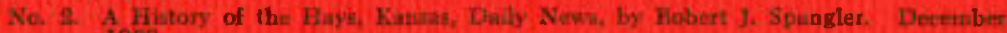
1903.

\section{Science Series}

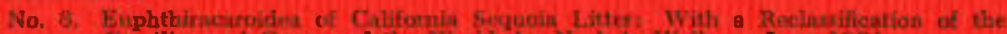

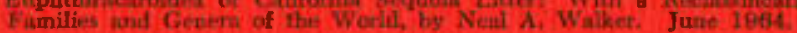

\section{Science Series}

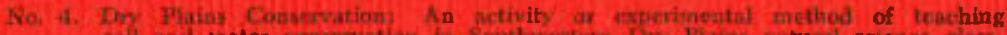

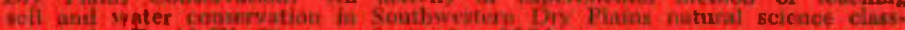

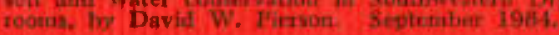

\section{Literahure Series}

\section{5}

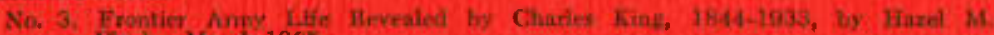
Fowk. Morch 1965. 
Helmut J. Schmeller

Hitler and Keitel: An Investigation of the Influence of Party Ideology on the High Command of the Armed Forces in Germany Between 1938 and 1945

Fort Hays Studies-New Series
History Series No.7
June 1970 


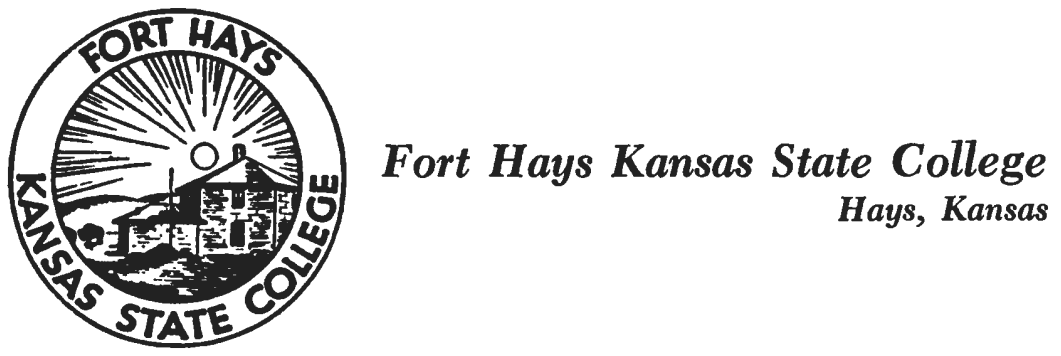

Fort Hays Studies Committee HARTLEY, THOMAS R. MARC T. CAMPBELL, chairman STOUT, ROBERTA C.

THORNS, JOHN C., JR.

WALKER, M. V.

Copyright 1970 by Fort Hays Kansas State College Library of Congress Catalog Card Number 72-631260 


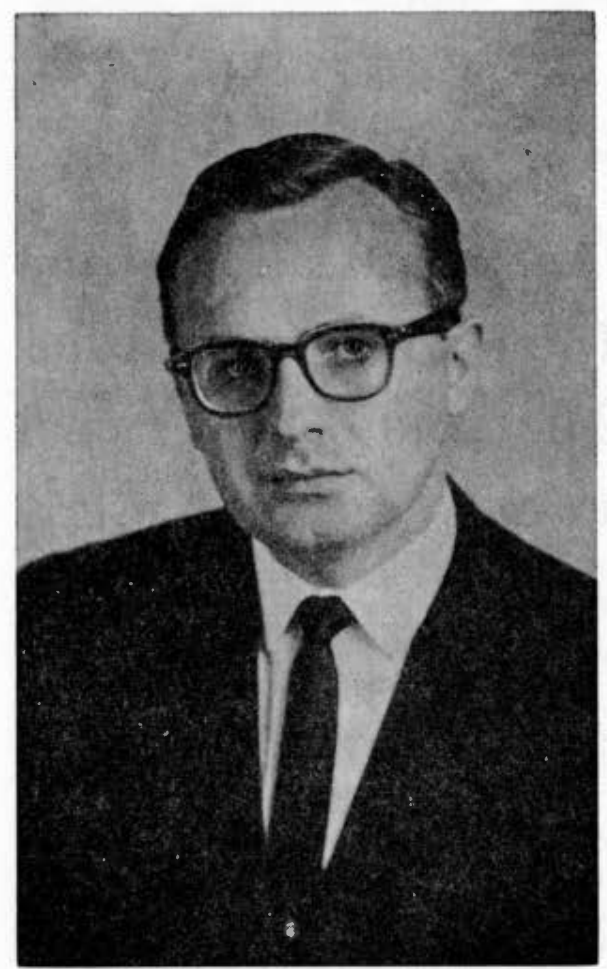

Helmut J. Schmeller

\section{Biographical Sketch of Author}

Helmut J. Schmeller studied philology and history at the Universities of Regensburg and Erlangen. He holds an M. A. degree in history from Fort Hays Kansas State College.

Mr. Schmeller joined the faculty at Fort Hays Kansas State College in 1966, where he is currently serving as assistant professor of history. 
Hitler and Keitel: An Investigation of the Influence of Party Ideology on the High Command of the Armed Forces in Germany Between 1938 and 1945 


\section{Preface}

Adolf Hitler's view of his own political mission rested upon the basis of his Weltanschauung ${ }^{1}$ and was therefore primarily a commitment to an ideology rather than a course of action dictated by pragmatic considerations. At the center of his ideology lay a personal belief that man's problems can and must be solved by force alone. $^{2}$ The preeminence of the role of force in Hitler's thinking was closely tied to his idea of what constitutes a strong and healthy nation. He saw the major cause of the decline of Germany after World War I as her inability to maintain the purity of the race just as he attributed the decline of all civilizations throughout history to a simple case of "blood poisoning" by inferior peoples." Although Hitler never defined exactly what he meant by "race" or "Aryan," he used these terms to demonstrate that there existed a fundamental inequality between peoples and nations.

In his mind, inequality was a law of nature and, as he reasoned in Mein Kampf, "All world historical events are only the expression of the racial instinct of self-preservation" of racial purity. ${ }^{4}$ A political system which was based upon equality of individuals and which operated on the basis of majority decisions he looked upon as the source of all the evils which had befallen mankind. Hitler publicly stated that there "are two closely related factors which we were able to trace time and time again in periods of national decline. One is that the levelling idea of the supremacy of the numbers-called democracy-is substituted for the concept of the value of the individual personality, and the other is . . . the denial of any difference in the inborn capacity of individual peoples." 5 Internationalism and democracy were therefore rejected in favor of a racially based nationalism and an elitist individualism. But individualism in Hitler's understanding of the word had nothing to do with the personal liberties and individual rights common to western tradition. "National Socialism takes as the starting point . . .

1. The term Weltanschauung in its original meaning (as used by Wilhelm Dilthey) stood for man's attempt to embrace entire reality in his philosophy of life. See Gerhard Masur, Prophets of Yesterday: Studies in European Culture 1890-1914 (New York: Harper Colophon Books, 1966), 164 ff.

Hitler, however, narrowed its meaning to an uncompromising ideological position which served as the basis for the philosophy and the program of the National Socialist German Workers Party.

2. Adolf Hitler, Mein Rampf (Muenchen: Zentralverlag der NSDAP., Franz Eher Nachf., 1944 ), p. 418.

3. Ibid., pp. $310,316$.

4. Ibid., p. 324 .

5. Speech by Adolf Hitler on January 27, 1932, at Duesseldorf, cited in Max Domarus (ed.), Hitler: Reden and Proklamationen 1932-1945, Vol. I: Triumph (2 vols.; Muenchen: Sueddeutscher Verlag, 1965), 71. 
neither the individual nor humanity. . . . It is important that the individual should slowly come to realize that his own ego is unimportant when compared with the existence of the whole people. . . ." 6

"The individual is transitory," Hitler said, "the Volk is permanent." National Socialism saw in the Volk "the blood conditioned entity" and a "God-willed building stone of human society." 7 The function of an individual thus became submerged in the organism of the Volk, like a cell becomes part of a larger living organism. That a racially alient element had no place in this organic body goes without saying. The maintenance of racial purity, which was necessary to insure the growth of a healthy and vigorous Volk, became thus one of the tasks of the Party.

But a growing Volk expands and expansion must mean contact with racially inferior peoples, i.e., a struggle for living space and raw materials in the East. At this point in Hitler's ideology everything fell into place: Marxism was seen as a threat to the voelkische community because it respected neither political nor ethnic boundaries. ${ }^{8}$ It was furthermore an invention and a tool of that "ferment of decomposition," the Jew, whose sole aim was to subjugate the Aryan peoples of the world for his own profiteering ends. The motives for the Jew's actions, however, ran even deeper: "In the last resort it is the Aryan alone who can form states and set them on their path to future greatness. All this the Jew cannot do; therefore his revolutions must be international . . . and with his envious instinct for destruction he seeks to disintegrate the national spirit of the Germans and pollute their blood." 9 The struggle against Marxism and the extermination of the Jews, whom Hitler considered to be the "biological basis of Bolshevism," 10 became interwoven with the struggle for living space and protection of the "Aryan peoples" against a weakening of their racially based strength.

The eventual struggle between these two Weltanschauungen, National Socialism and Marxism, needed to be translated into reality: "Therefore an instrument must be created for the voelkische Weltanschauung, which enables it to fight, just as the Marxist party organization creates a free path for internationalism." 11 The Pro-

\footnotetext{
6. Speech by Adolf Hitler on October 7, 1933, at Bueckeburg, cited in Alan Bullock, Hitler: A Study in Tyranny (compl. rev. ed.; New York: Harper \& Row, Publishers, 1962), p. 401.

7. Ibid.

8. Bullock, Hitler, p. 406.

9. Speech by Adolf Hitler on July 28, 1922, ibid., p. 407.

10. Hitler, Mein Kampf, p. 498.

11. Ibid., p. 423.
} 
gram of the National Socialist German Worker's Party proposed in Point 22 the creation of a People's Army. ${ }^{12}$ This idea, however, never materialized because of the opposition of the Reischswehr. Consequently, Hitler, after becoming Chancellor of the Weimar Republic in 1933 through various manipulations of commanders, sought to gain control of the Reichswehr, the strongest non-political institution in the state. After 1941 he intensified his attempts to make the Wehrmacht the tool of National Socialist ideology. It is the purpose of this study to trace Hitler's evolving program of using the military to accomplish his political ends.

12. Das Programm der Nationalsozialistischen Deutschen Arbeiterpartei cited in Dr. Hans-Adolf Jacobsen and Dr. Werner Jochmann, (eds.), Ausgewaehlte Dokumente zur Geschichte des Nationalsozialismus 1933-1945 (Bielefeld: Neue Gesellschaft G. m. b. H., 1961), n. p. 


\section{Table of Contents}

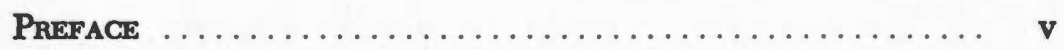

CHapter

I. The Mirtary Establishment and National Socialist IdEOLOGY $\ldots \ldots \ldots \ldots \ldots \ldots \ldots \ldots \ldots \ldots \ldots \ldots \ldots \ldots \ldots \ldots$

II. Mimitary Tradition in the Inter-War Period ....... 11

III. The Ruse of General Ketrel AND the OKW . . . . . . . 17

IV. The Traditional Soldigr in the Totalitarian State. . . 29

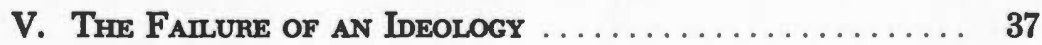

VI. Conctuston $\ldots \ldots \ldots \ldots \ldots \ldots \ldots \ldots \ldots \ldots \ldots \ldots \ldots$

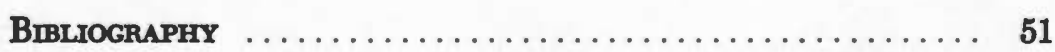




\section{Chapter I}

\section{The Military Establishment and National Socialist Ideology}

The former President of the Senate of the Free City of Danzig, Hermann Rauschning, once pointed out Adolf Hitler's lack of interest in the details of a problem unless it concerned the Army or foreign policy. ${ }^{1}$ Considering the prominent position of the military establishment in recent German history, Hitler's concern with military matters would in itself not seem to be out of the ordinary. His front-line experience as a common soldier in the First World War, which seems to have been the most formative experience of his life, ${ }^{2}$ together with his pseudo-Darwinian views of the preeminence of struggle in the life of a nation, ${ }^{3}$ may serve to explain in part his almost obsessive preoccupation with things military. His activities as an "Educational Officer" in the immediate postwar period not only helped him maintain his ties with the Army but also contributed greatly to his extremely negative attitude towards the Weimar Republic and all it stood for. ${ }^{4}$

The picture of the German Army of the First World War as it emerges from the pages of Mein Kampf stresses the Army's role as a bulwark against the evils of parliamentarianism and materialism. The Army is shown as the preserver of the ideals of devoted service to the country and of the individual's sacrifice for the general welfare of the people." "What many Germans . . . did not wish to see, the alien world around them recognized: The German Army was the most powerful weapon in the service of the freedom of the German nation and in the support of the nation's children." 6 The Army of the future, so Hitler argued, must preserve these traditional values; in addition it must act as a unifying factor in overcoming regional sentiments and loyalties. ${ }^{7}$ The Army was also to remain

\footnotetext{
1. Hermann Rauschning, Hitler Speaks: A Series of Political Conversations With Adolf Hitler on His Real Aims. (London: Thornton and Butterworth Ltd., 1940), p. 183.

2. Adolf Hitler, Mein Kampf (Muenchen: Zentralverlag der NSDAP., Franz Eher Nachf., 1944), p. 225.

3. Speech by Adolf Hitler on March 15, 1929, cited in Dr. Otto Ernst Schueddekopf, Das Heer und die Republik: Quellen zur Politik der Reichswehrfuehrung 1918-1933 (Hannover: Norddeutsche Verlagsanstalt O. Goedel, 1955), p. 281.

4. Hitler, Mein Kampf, p. 235.

5. Ibid., p. 307.

6. Ibid., p. 308 .

7. Ibid., p. 647 .
} 
the "school of the nation" in the coming order, but its educational role was to be considerably widened. In his discussion of the voelkische state, Hitler emphasized that one of the tasks of this type of education was to create in the individual the desire to preserve his racial purity. The completion of the educational process in the voelkische state culminates in the military service which "must be regarded as the conclusion of the average German's normal education." 8 Although Hitler's ideas concerning the nature and role of the Army in the new state were in 1924 by necessity very general, they contain the basic elements of his later thoughts and actions: creation of an essentially political, i.e., National Socialist oriented Army which, highly centralized and possessed by a spirit of loyalty and devotion as it had existed in the trenches of the First World War, would serve as an important factor in the life of the National Socialist state.

These basic ideas were developed further in a speech by Hitler in 1929 in which he declared: "Reichswehr or militia, people's army or standing army or whatever, is for us National Socialists only a means to an end. Our criterion will forever be: is it useful to our Volk? Because the Volk is to us a higher concept than the concept of the state. It is conceivable that a state is rotting and decaying and that the Volk must destroy such a state because its very life demands it." 9 At the same occasion Hitler condemned the Reichswehr's principle of Ueberparteilichkeit ${ }^{10}$ and declared it to be the mission of the Army to "exterminate the vermin of party politics." He compared the national defense policy of the Social Democratic Party (SPD) with the policy of his own movement and stated that his party, if victorious, would make every effort to create military formations outlawed by the treaty of Versailles. The most significant statement of the speech, in the light of future developments, was Hitler's definition of the relationship between the Army and politics: "To the extent that the political leadership is lacking an understanding of military leadership, to that extent the military itself must become the carrier of a political ideology." 11

The creation of a new class of leaders to replace the ruling class of the past was discussed by Hitler in the summer of 1932 at the

8. Ibid., p. 476 .

9. Speech by Adolf Hitler on March 15, 1929, cited in Schueddekopf, Das Heer und die Republik, p. 281.

10. The term Ueberparteilichkeit denotes the policy of the Reichswehr to keep above politics. This policy goes back to an order by Colonel General Hans von Seeckt, Chief of the Army Command of the Reichswehr, which was issued following the Kapp Putsch of March, 1920. See Gordon A. Craig. The Politics of the Prussian Army 1640-1945 (New York: Oxford University Press, 1964), p. 386.

11. Speech by Adolf Hitler on March 15, 1929, cited in Schueddekopf, Das Heer und die Republik, pp. 283, 286. 
Brown House, the headquarters of the National Socialist Party in Munich. Speaking to a small circle of party comrades, Hitler explained: "The selection of the new Fuehrer class is my struggle for power. Whoever proclaims his allegiance to me is by this very proclamation and by the manner in which it is made one of the chosen. This is the great revolutionary significance of our long, dogged struggle for power that in it will be born a new Herren-class chosen to guide the fortunes not only of the German people, but of the world." 12 That the leaders of the Army as well as the leaders of the important organs of the state would have to be included in this new Fuehrer class seems obvious. The cleavage between the Reichswehr's concept of "splendid isolation from politics" 13 and these new concepts was to become increasingly apparent in the months following Hitler's assumption of the Chancellorship of the German Reich on January 30, 1933.

As Chancellor, Hitler was at last in an official position from which to influence the policies directly affecting the military establishment. His new position, however, also put him on the horns of a dilemma. The existence of large, armed formations of Sturmabteilungen (SA) ${ }^{14}$ under their aggressive Chief of Staff, Captain Ernst Roehm, had to be reconciled with the existence of the Reichswehr as the traditionally sole military establishment. On February 3 , 1933, Hitler addressed the Commanders of the Army and the Navy at the occasion of the appointment of the new Reich Defense Minister, Major General Werner Eduard Fritz von Blomberg. Hitler emphasized that the Reichswehr was to remain the sole arms bearer in Germany and that an amalgamation of Party and Army formations on the Italian example was out of the question. ${ }^{15}$ Hitler's attitude seems to have been gratefully appreciated by the leaders of the Armed Forces, especially by von Blomberg and the new Chief of the Ministeramt in the Defense Ministry, Colonel Walther von Reichenau. ${ }^{16}$ The relationship between the Armed Forces and the SA was also the subject of Hitler's speech in Bad Godesberg on August 19, 1933, when he pointed out that the relationship of the

12. Rauschning, Hitler Speaks, p. 49.

13. Walter Goerlitz, "Wallensteins Lager 1920-1938: Das Verhaeltnis der deutschen Generalitaet zur Republik und zum Nationalsozialismus," Frankfurter Hefte, No. 5 (May, 1948 ), 416.

14. The Sturmabteilungen (SA) or Storm Troopers were an irregular National Socialist Militia.

15. Speech by Adolf Hitler on February 3, 1933, at Berlin to the Commanders of the Army and Navy cited in Max Domarus, (ed.), Hitler: Reden und Proklamationen 19321945, Vol. I: Triumph ( 2 vols.; Muenchen: Sueddeutscher Verlag, 1965), 198.

16. Ibid., pp. 197-198, n. 68. The Ministeramt was the office of the Defense Minister within the Ministry of Defense. Colonel Walther von Reichenau had been Chief of Staff to von Blomberg in Koenigsberg, East Prussia. Colonel von Reichenau is generally described as an ardent National Socialist. See Robert J. O'Neill, The German Army and the Nazi Party 1933-1939 (New York: James H. Heineman, Inc., 1966), p. 30. 
SA to the Army was the same as the relationship between the political leadership and the Army. Both institutions were not to be regarded as a purpose in themselves but were to serve only one purpose, the preservation of the Volk. ${ }^{17}$

The continuing conflict betwen Roehm's intentions to make the SA the truly revolutionary army of the movement ${ }^{18}$ on one hand and the Reichswehr's insistence on its position as the sole bearer of arms in the nation on the other hand began to force Hitler into a position even more favorable to the Army. In a speech to the generals of the Reichswehr on February 28, 1934, Hitler not only confirmed the Reichswehr's desired position but relegated the SA to political tasks in the interior of the country. ${ }^{19}$ Roehm fully recognized the implications of this shift in Hitler's attitude towards the SA and accused Hitler of betraying the revolution. ${ }^{20}$

Among the reasons for Hitler's siding with the Reichswehr was the necessity of keeping his obligation to the Reich President Field Marshal Paul von Hindenburg as well as his desire to keep on good terms with the Reichswehr. ${ }^{21}$ Aside from the fact that he was hardly in a position to quarrel with his new and still powerful friends in the Defense Ministry, Hitler realized that the future belonged to an army of professionals. "But the best of these professional troops cannot be selected on the basis of their revolutionary feelings or their status in the party, but solely on their technical qualifications. I can't seriously be expected to draw the material for my military elite from the bow-legged and knock-kneed SA." 22 The former revolutionary, Hitler, who had now become Adolf Legalité, had to rid himself of the army of street brawlers and terrorists which had become an organization without a function now that its erstwhile leader had become legitimate.

The probability of the Reich President's impending death provided an impetus for a series of events which culminated in the disappearance of the SA as an organization of military significance.

17. Speech by Adolf Hitler to the SA and SS Leadership Conference at Bad Godesberg on August 19, 1933, cited in Domarus, Hitler, I, 293.

18. Herbert Rosinski, The German Army, ed. Gordon A. Craig (New York: Frederick A. Praeger, Publishers, 1966), p. 192; Konrad Heiden, Der Fuehrer: Hitler's Rise to Power, trans. Ralph Manheim (Boston: Houghton Miflin Co., 1944), p. 746.

19. Speech by Adolf Hitler to the Generals of the Reichsweht on February 28, 1934, cited in Domarus, Hitler, I, 368.

20. Rauschning, Hitler Speaks, pp. 154-155. Roehm expressed his disappointment with Hitler: "Adolf is a swine. He will give us all away. He only associates with the reactionaries now. His old friends aren't good enough for him. Getting matey with the East Prussian generals. . . . Are we revolutionaries or aren't we? . . I'm the nucleus of the new army, don't you see that? Don't you understand that what's coming must be new, fresh and unused? The basis must be revolutionary. You can't inflate it afterwards. . . . But Hitler puts me off with fair words."

21. Alan Bullock, Hitler: A Study in Tyranny (compl. rev. ed.; New York: Harper \& Row, Publishers, 1962), p. 268; Craig, The Politics of the Prussian Army 1640-1945, p. 475.

22. Rauschning, Hitler Speaks, p. 185. 
At a meeting in Bad Nauheim on May 16, 1934, the senior officers of the Ministry of Defense and the Inspectorates of the Army decided to accept Hitler as successor to the Reich President after von Blomberg told them of an understanding he had reached with Hitler. According to this understanding, Hitler had promised to eliminate the $\mathrm{SA}$ in return for the Presidency. ${ }^{23}$ The exact nature of this agreement and the circumstances surrounding it seem to be the matter of some controversy. Alan Bullock, one of Hitler's biographers, believes that Hitler came to an agreement with the Reichswehr leaders on that matter during his stay on the cruiser Deutschland in April, 1934. ${ }^{24}$ Some German historians, however, claim that sufficient evidence for the existence of such an agreement between Hitler and the Reichswehr generals is lacking. ${ }^{25}$ Whatever the exact nature of that agreement may have been, the Chief of Staff of the SA and other inconvenient opponents of Hitler's recent policies did find an inglorious end in the Blood Purge of June 30, 1934. ${ }^{26}$

It has been pointed out that the Reichswehr played the role of a pretorian guard during the events of June $30,1934 .{ }^{27}$ Although Hitler was soon to destroy such pretensions, there were no advanced indications of this in 1934. Years later, Field Marshal von Blomberg testified at the Nuremberg Trials that the generals considered much of what Hitler said as just so much propaganda that need not be taken seriously. ${ }^{28}$ "The personal oath to Hitler [and] the appearance of the Wehrmacht at the Nuremberg Party Congress in September [1934], seemed a modest enough price for the apparent restoration of the military monopoly and the apparent institutional sovereignty that went with it." 29

The complete satisfaction of the Reichswehr with the outcome of the purge was summed up in von Blomberg's Order of the Day of July 1, 1934: "The Fuehrer has personally attacked and destroyed the traitors and mutineers with exemplary courage and soldierly decisiveness. The Wehrmacht as the arms bearer of the entire Volk, aloof from political conflict, will again pledge devotion and fidelity. Aware of the common ideals, the Wehrmacht will joyfully cultivate

23. John W. Wheeler-Bennett, The Nemesis of Power: The German Army in Politics 1918-1945 (2d ed.; London: Macmillan \& Co., Ltd., 1964), p. 313.

24. Bullock, Hitler, p. 290.

25. Herman Mau and Helmut Krausnick, Deutsche Geschichte der iuengsten Vergangenheit 1933-1945 (Tuebingen: Rainer Wunderlich Verlag Hermann Leins; Stuttgart: J. B. Metzlersche Verlagsbuchhandlung, 1964 ), p. 62.

26. Bullock, Hitler, p. 303.

27. Michael Freund, Deutschland unterm Hakenkreuz: Die Geschichte der Jahre 19331945 (Guetersloh: C. Bertelsmann Verlag, 1965), p. 63.

28. International Military Tribunal, Trial of the Maior War Criminals Before the International Military Tribunal, XL (42 vols.; Nuremberg: International Military Tribunal, 1949), 406. (Hereafter cited as IMT.)

29. David Schoenbaum, Hitler's Social Revolution: Class and Status in Nazi Germany 1933-1939 (Garden City, N. Y.: Doubleday \& Company, Inc., 1967), p. 207. 
cordial relations with the new SA." 30 Even the Reich President felt that he had to congratulate the Prussian Minister President and now General of the Infantry, Hermann Goering, on his success in "defeating the attempt to commit treason." 31 The rewards for the Reichswehr's silence of complicity were soon to come. In his Reichstag Speech of July 13, 1934, Hitler reminded the Reichswehr that he had argued for fourteen years that the fighting organizations of the Party had nothing to do with the Army, that he had clearly stood by his original position and that "there is only one bearer of the arms in the state: the Wehrmacht. And there is only one source of the political will: the National Socialist Party." 32

The entire affair of mutual reassurances of trust and devotion was not without overtures from the Army. On the day before the purge of the SA, von Blomberg had elaborated on the position of the Wehrmacht in the Third Reich in an article in the official Party organ, the Voelkischer Beobachter. He explained that the Army would serve the new state and its leadership from deepest conviction and assured his readers of the loyalty of the Army to the President and to the Fuehrer, "who once came from our ranks and will always remain one of us." 33

At the time of the death of the Reich President on August 2, 1934, the small number of opponents to Hitler's presidential ambitions were divided among themselves and without influence on the course of events. ${ }^{34}$ Hitler's Cabinet had acted with speed, and on the night before the President's death, it had decreed the "Law Concerning the Head of State of the German Reich" which unified the office of Reich President with that of the Chancellor. The law was to become effective at the moment of the old President's death. ${ }^{35}$ This act allowed Hitler to unite in his person the offices of President of the Reich, Supreme Commander of the Armed Forces, Chancellor of the Reich, and Fuehrer of the National Socialist Party. This is not to say, however, that Hitler was now in full command of the Armed Forces. Technically all orders of the President concerning the military establishment had to be countersigned by either the Chancellor or, as was customary, the Defense Minister. ${ }^{36}$ ibid.

31. Telegram from the Reich President to Hermann Goering, date July 2, 1934, cited in

32. Speech by Adolf Hitler to the German Reichstag on July 13, 1934, cited in ibid., p. 417.

33. Voelkischer Beobachter, June 29, 1934, ibid., 393.

34. Wheeler-Bennett, The Nemesis of Power, p. 331.

35. "Law Concerning the Head of State of the German Reich" of August 1, 1934, cited in Domarus, Hitler, I, 429.

36. Friedrich Hossbach, Zwischen Wehrmacht und Hitler 1934-1938 (2d ed. rev.; Goettingen: Vandenhoeck \& Ruprecht, 1965), p. 54. 
With the compliant von Blomberg heading the Defense Ministry there would have been no obstacle to Hitler's exercise of full control over the Armed Forces, but Hitler appears to have been aware of the fact that von Blomberg was not representative of the entire Army leadership. Never one to force things at an inopportune moment, Hitler wisely kept himself in the background and, for the time being, appears to have been content to exercise his powers as Supreme Commander only nominally. ${ }^{37}$

The significance of the fusion of the office of Reich President with that of Reich Chancellor lay in the fact that it opened the way to one-man rule. It had enabled Hitler to become Supreme Commander of the Armed Forces in a quasi-legitimate fashion. ${ }^{38}$ This fact was duly emphasized by von Blomberg's order of August 2, 1934 , to the troops to take a personal oath of loyalty to Hitler. ${ }^{39}$ The text of this fateful oath deviated from the wording of the past oath in that it established a personal tie of loyalty between the officers and men of the Wehrmacht and Hitler rather than a pledge of loyalty to the country or the government. ${ }^{40}$ Hitler's reply to what appears to have been a voluntary action on von Blomberg's part made the meaning of the oath even clearer, and, whether intentionally or not, reminded the Army leaders that an old bargain had been fulfilled. "Just as the officers and soldiers of the Wehrmacht have pledged themselves to the new state in my person, so will I at all times regard it as my highest duty to intercede in behalf of the stability and inviolability of the Wehrmacht . . . in accordance with my own desire to fix (verankern) the army as the sole bearer of arms (einziger Waffentraeger) in the nation." 41

Although Hitler abstained from direct interference in internal Army matters for the time being, he began to consolidate his position as Supreme Commander through a series of legislative acts. The Wehrgesetz of May 21, 1935, gave to the Reich War Minister the additional title of Commander in Chief of the Armed Forces and to Hitler the title of Supreme Commander of the Armed Forces. The law provided that the Reich War Minister exercise his func-

37. Ibid., p. 64.

38. Michael Freund argues that the appointment of Hitler was in direct violation of the Enabling Law which provided that the government could change the constitution but could not abolish the office of Reich President. Freund, Deutschland unterm Hakenkreuz, p. 63.

39. Hossbach, Zwischen Wehrmacht und Hitler, p. 65.

40. The text of the oath reads: "I swear by God this holy oath that I will render to Adolf Hitler, Leader of the German nation and people, Supreme Commander of the Armed Forces, unconditional obedience, and I am ready as a brave soldier to risk my life at any time for this oath." Cited in O'Neill, The German Army and the Naxi Party, 1933-1939, p. 55.

Freund argues that the oath was invalid because the Cabinet legalized it after the soldiers had taken it. In addition, the soldiers were already under oath to the constitution. Freund, Deutschland unterm Hakenkreuz, p. 71.

41. Letter by Hitler to von Blomberg, date August 20, 1934, cited in Craig, The Politics of the Prussian Army, p. 480. 
tions under the direction of the Supreme Commander and contained no provision that orders by the Supreme Commander required the countersignature of either the War Minister or the Chancellor. ${ }^{42}$

While the leadership of the Armed Forces were kept busy implementing the new laws regulating conscription and military service, ${ }^{43}$ Hitler made plain to the nation at large and to those in the Armed Forces who wanted to know what were the legal technicalities of the new Wehrgesetz and the new oath. "The two pillars of the new Reich may keep in mind that only acting as one can they fulfill their tasks. The Party gives the Army to the Volk, and the Volk gives the soldiers to the Army; both jointly give to the German Reich the security of inner peace and the strength for maintaining its position." 44

On the newly established "Day of the Wehrmacht," Hitler drew a line of distinction between the old Reichswehr and the new Wehrmacht. In his "Speech to the Soldiers" he referred to the assembled troops as the "new soldiers of the new German Reich." 45 A few weeks later the new soldiers were told in the Order of the Day of November 7, 1935, that the swastika which now decorated the new war flag should be to them "the symbol of unity and purity of the nation, signifying the strength of the National Socialist Weltanschauung." 46 There were neither protests nor actions by the leaders of the Armed Forces against this continuing injection of political slogans, symbols, and ideas into the military system. Any opposition of Army leaders against the regime would have been opposition against the legitimately constituted authority of the state to which officers and men were bound by a personal oath of loyalty.

A series of internal events, such as the Fritsch Crisis, brought in their wake a further drastic change in the relationship between Hitler and the Army. The chain of intrigues, scandals, and accusations affected the entire higher command structure of the Armed Forces and found its final expression in Hitler's "Decree Concerning the Leadership of the Armed Forces" in which Hitler announced that he would now exercise the power of command over the Armed Forces "directly and personally." The Decree also announced the

42. Wehrgesetz, May 21, 1935, cited in Dr. Hans-Adolf Jacobsen and Dr. Werner Jochmann (eds.), Ausgewaehlte Dokumente zur Geschichte des Nationalsozialismus 19331945 (Bielefeld:" Neue Gesellschaft G. m. b. H., 1961), n. p. The Wehrgesetz designated von Blomberg as Reich War Minister rather than Reich Defense Minister.

43. Conscription had been introduced by the Gesetz fuer den Aufbau der Wehrmacht of March 16, 1935, ibid., n. p.

44. "Final Speech" by Hitler to the Party Congress at Nuremberg in September, 1935, cited in Domarus, Hitler, $\mathbf{1}, \mathbf{5 4 1}$. 539.

45. "Speech to the Soldiers" by Hitler on September 16, 1935, at Nuremberg, ibid.,

46. Order of the Day of November 7, 1935, by Hitler, ibid., 549. 
creation of a High Command of the Armed Forces (Oberkommando der Wehrmacht or OKW) which was to operate directly under Hitler's command as his military staff. ${ }^{47}$ At the same time, Colonel General Baron Werner Thomas Ludwig von Fritsch and Field Marshal Werner von Blomberg received Hitler's letters of appreciation for past services in which the Fuehrer expressed his desire that their health might soon improve. ${ }^{48}$ In rapid succession, on the same day, a series of military appointments was announced, the most important of which made Colonel General Herman Goering a Field Marshal, General Walther von Brauchitsch Commander in Chief of the Army, and General Wilhelm Keitel Chief of the High Command of the Armed Forces. ${ }^{49}$

47. Erlass ueber die Fuchrung der Wehrmacht of February 4, 1938, by Hitler, cited in Domarus, Hitler, I, 782.

48. Letters by Hitler to von Blomberg and von Fritsch, date February 4, 1938, ibid., 783. Von Fritsch was relieved of his duties as Commander in Chief of the Army because of his supposed involvement with a homosexual ex-convict. Von Blomberg was relieved of his duties because of his marriage to a lady with a questionable background. See WheelerBennett, The Nemesis of Power, p. 367.

49. Letter of appointment of Wilhelm Keitel by Hitler, date February 4, 1938, cited in Domarus, Hitler, I, 783. 



\section{Chapter II}

\section{Military Tradition in the Inter-War Period}

"It was a point of honor with the Prussian officer to be correct, it is a duty of the German officer to be crafty." 1 This statement by von Blomberg expressed not only the tragic deterioration of the traditional concept of honor but also characterized very well the narrow class outlook of that older generation of officers whose prime concern in their relationship with the state was to serve the interests of the Army. Craftiness, however, was not the answer to the problems which confronted the senior officers after 1933.

To some extent these problems had been caused by the numerical increase of officers in the new Wehrmacht. Whereas the old 100,000-man Reichswehr had listed 4,000 officers, the Army in 1939 listed a total of 24,000 officers. $^{2}$ The older generation of officers viewed the new arrivals with a great deal of misgiving and suspicion. $^{3}$ They were, after all, not the product of von Seeckt's school of thought ${ }^{4}$ but, in many cases, the products of previous schooling in the Hitler Youth, the SA, or the Reich Labor Service. ${ }^{5}$ The older officers had seen the purpose of the 100,000-man Army as a vessel in which to transmit the traditional values of the soldier's profession and had favored an organic growth based on these values. The newcomers had little or no understanding of these values and were much more impressed with the modern and aggressive spirit of the National Socialist movement. ${ }^{6}$ To what extent the former members of the Free Corps found a place in the new Army has not been established. Their contribution to the Army seems to have been indirect: many of them rose to positions of power in the National Socialist state from where they were able to pass on to the new generation their "brutality of spirit and exaltation of power." 7

Aside from the numerical increase and the resulting inability of the senior officers to weld the Corps into a homogeneous and cohe-

\footnotetext{
1. Field Marshal Werner von Blomberg quoted in Hermann Rauschning, The Revolution of Nihilism: Warning to the West (New York: Alliance Book Corporation, 1939), p. 123.

2. Hermann Foertsch, Schuld und Verhaengnis: Die Fritsch-Krise im Fruehjahr 1938 als Wendepunkt in der Geschichte der nationalsozialistischen Zeit (Stuttgart: Deutsche Verlagsanstalt, 1951 ), p. 106.

3. Peter Bor, Gespraeche mit Halder (Wiesbaden: Limes Verlag, 1950), p. 106.

4. See Chapter I, n. 10.

5. Foertsch, Schuld und Verhaengnis, p. 181.

6. Bor, Gespraeche mit Halder, p. 107.

7. Robert G. Waite, Vanguard of Nazism: The Free Corps Movement in Post War Germany 1918-1923 (Cambridge, Mass.: Harvard University Press, 1952), p. 281.
} 
sive unit, ${ }^{8}$ another and much more profound problem confronted the older generation. The traditional concept of honor in the Prussian Army had always been tied to the monarch. ${ }^{9}$ But with the disappearance of the monarchy, a void was created. "In the absence of spiritual directives," a former Prussian officer wrote in 1939, "from which the officers are suffering at the moment, with their two elements of guidance, the Crown and the Christian Church taken from them, they are reduced to spiritual Ersatz, cheap substitutes of doubtful origin and efficacy." 10 While the experience of the First World War had already contributed to a heightening of the moral value of absolute obedience, ${ }^{11}$ this process not only continued but was considerably strengthened during the Seeckt era. ${ }^{12}$ In 1923 von Seeckt declared: "A soldier's honor does not lie in knowing better or having better ideas, but in obeying." 13 The disastrous consequences of this attitude became clear at Nuremberg in 1945 when General Colonel Alfred Jodl said: "I have been an obedient soldier and I saw my honor in keeping that obedience which I had sworn. . . . I have in these five years worked and I have remained silent, although I often held a different opinion, and recognized that impossible nonsense which I was ordered to perform." 14 As absolute obedience became a moral absolute, and as such the basis of an officer's honor, the oath of loyalty now sworn to the person of the Fuehrer was soon to create a dilemma which many of the older officers were unable to resolve. Some attempted to resign, others took flight into professionalism and talked about the traditional Ueberparteilichkeit of the Army, but the overwhelming majority thought that they had to continue to serve the state. After the end of the Second World War, von Blomberg reflected: "I have never been aware of an action or an opposition of the generals against Hitler and his National Socialist Program. Through his program of rearmament he brought the generals the fulfillment of old desires. During my ministry Hitler attempted to stand by the traditions of the soldiers in every respect. If so many generals now deny their attitudes towards Hitler during these years, memory must have played a trick on them." 15

\footnotetext{
8. Rauschning, Revolution of Nihilism, p. 152.

9. Karl Demeter, Das Deutsche Offizierkorps in Gesellsschaft und Staat 1650-1945 (4th ed. rev. and expanded; Frankfurt am Main: Bernard \& Graefe Verlag fuer Wehrwesen, $1965)$, p. 151.

10. Rauschning, Revolution of Nihilism, p. 152.

11. Demeter, Das Deutsche Offizierskorps, p. 147.

12. Herbert Rosinski, The German Army, ed. Gordon A. Craig (New York: Frederick A. Praeger, Publishers, 1966), p. 167.

13. Demeter, Das Deutsche Offizierskorps, p. 148.

14. Ibid., p. 151.

15. Foertsch, Schuld und Verhaengnis, p. 182.
} 
The lack of concern over the political ideology of the Nazi movement and the narrow class interests of the older members of the corps of officers were to a great degree the result of the Corps' traditional relationship in the state. Like the concept of honor, the relationship of the officers to the state had traditionally been characterized by the link between monarch and officer. As such the Corps' responsibility lay neither with the people nor with the state but rather with its source of existence, the crown. ${ }^{16}$ Under the Weimar Republic and von Seeckt's guidance, the majority of officers felt little allegiance to either the Republic or the Constitution. ${ }^{17}$ Their allegiance lay rather with a somewhat nebulous concept, a kind of "permanent state" which according to von Seeckt was represented by the Army. ${ }^{18}$ General Wilhelm Groener, Reichwehrminister from 1928 to 1932 , defined the functions of the Army in 1930 in these words: "It is the sacred task of the Wehrmacht to prevent the cleavage between classes and parties from ever widening into suicidal civil war. In all times of need . . . there is one unshakable rock in the stormy sea: the idea of the state. The Wehrmacht is its necessary and most characteristic expression. It has no other interest and no other task than service to the state. . . . [The Wehrmacht] would falsify its essence and destroy itself if it descended into the party conflict and itself took party." 19

Although Ueberparteilichkeit served the nation well during times of crises, it also had serious drawbacks: not only was the Army "above parties," it also was above identifying itself with the Republic, with parliament, or with the Constitution..$^{20}$ In short, the Army existed outside the political reality of the Weimar Republic and attempted to function in a world of its own, guided by vague concepts of a by-gone era.

Dr. Julius Leber (SPD), one of the parliamentary specialists on Wehrmacht questions, recognized this problem as early as 1931 when he pointed out that obedience was not enough and that the soldier "must have a mental image of what his task consists of" and should recognize a set of ideals which he could follow. ${ }^{21}$ Many of the younger officers had already found such ideals in the new revolutionary movement of the National Socialists. Thus the real significance of the Ulm treason trials in 1930, involving Reichswehr officers with National Socialist leanings, was that they brought to

18. Demeter, Das Deutsche Offizierskorps, p. 182.

17. Gordon A. Craig, The Politics of the Prussian Army 1640-1945 (New York: Oxford University Press, 1964 ), p. 426.

18. Ibid., pp. 388-389.

19. Decree of the Reichswehr Ministry of January 22, 1930, cited in ibid., p. 433.

20. Demeter, Das Deutsche Offizierkorps, p. 190.

21. Ibid., p. 191. 
the open for the first time that rift in the Corps of Officers which separated the old generation of officers from the young not only in terms of their background and previous service but, most important of all, in terms of the ideals to which they adhered. ${ }^{22}$ General von Seeckt's thesis of the all-importance of discipline and obedience to authority had obviously proven to be insufficient motivation for the defendants and their sympathizers. The counsel for the defense at the Ulm treason trials asked the poignant question: "How is the soldier expected to sacrifice his life for people who say they know no fatherland called Germany?" He continued his argument adding that the soldier must put his country above the Constitution when the provisions of the Constitution are executed by traitors who are not cultivating a spirit of national defense. ${ }^{23}$

Although it appears that this type of attitude was not confined to junior officers only, the extent to which general officers subscribed to it is difficult to determine. General Walther Reinhardt observed that two thirds of the young Reichswehr officers realized, as he did, that there was a pressing need for new ideals in the Army because whatever the Republic had to offer in that respect was meaningless to most of the officers. ${ }^{24}$ General Hans Oster wrote in 1944 that most of the officers looked upon the events of 1933-1934 as a return to earlier traditions and, for that reason alone, welcomed National Socialism. They did not understand, he added, what was meant by phrases like "synthesis of party and state"; what was foremost in their minds was the rebuilding of the Army into a truly patriotic instrument. ${ }^{25}$ This attitude was apparently characteristic of a number of the senior officers. Their attitude towards the National Socialist state was primarily determined by their interests as a professional class rather than by sympathy for the entire National Socialist program. Their traditional aversion to politics and their exaggerated concept of loyalty and obedience were to prove invaluable assets for a political manipulator of Hitler's skill.

The junior officers, however, who had gone through training in the Hitler Youth or the Reich Labor Service were to provide an

22. The defendants were Lieutenant Richard Scheringer and Lieutenant Hans Ludin. Their ultimate objective was to gain the support of the Officer Corps in the event of a Nazi Revolution. They were sentenced by the Supreme Court of the Reich at Leipzig on October 4,1930 , to eighteen months of fortress detention for conspiracy to commit high treason. See John W. Wheeler-Bennett, The Nemesis of Power: The German Army in Politics 19181945 (2d ed.; London: Macmillan \& Co., Ltd., 1964), pp. 214-220 passim.

23. Dr. Sack, "Das Ringen fuer Blut und Ehre," Voelkischer Beobachter, October 10, 1930, cited in Dr. Otto Ernst Schueddekopf, Das Heer und die Republik: Quellen zur Politik der Reichswehrfuehrung 1918-1933' (Hanover: Norddeutsche Verlagsanstalt $O$. Goedel, 1955 ), p. 269.

24. Ibid.

25. Demeter, Das Deutsche Offizierskorps, pp. 326-327. 
ever increasing percentage of Nazi sympathizers within the Armed Forces. ${ }^{26}$ Thus the German Officer Corps by 1938 was no longer a homogeneous unit as in the era of von Seeckt. Internally divided and lacking a truly unifying philosophy, the Corps presented a picture not unlike the Weimar Republic, which it so detested.

26. Robert J. O'Neill, The German Army and the Nazi Party 1933-1939 (New York: James H. Heineman, Inc., 1966), p. 95. 



\section{The Rise of General Keitel and the OKW}

Wilhelm Keitel was born on September 22, 1882, in Helmscherode, where he spent his early life at his father's farm. He attended secondary school at Goettingen and, during his senior year, toyed with the idea of taking a commission in the Field Artillery, simply because "they had horses." His father's second marriage prevented Keitel's return to the farm: financial problems and the size of the farm made it impossible to sustain two families. ${ }^{1}$ On March 7, 1901, he entered the Lower Saxon Field Artillery Regiment No. 42. ${ }^{2}$ In August, 1914, when World War I began, Keitel, now a Lieutenant with the Wolfenbuetteler Field Artillery Regiment, crossed the Belgian border with his troops. ${ }^{3}$ He served for a time as battery commander, was promoted to Captain, and in March, 1915, was assigned to a General Staff position with the X Reserve Corps. ${ }^{4}$ His letters to his wife and to his father during that period expressed his pride over the last appointment but also his inadequate preparation for the task. ${ }^{5}$

Like most other officers, he was shocked by the outbreak of the revolution in Germany in 1918: "Those of us who have known discipline and order as the symbols of a German soldier's virtue have had a terrible experience. . . . I think that we will be able to create a viable state through the National Assembly and that we shall be able to overcome gradually the consequences of the revolution and the wretched war. Both could have been avoided anyhow." 6

After the war Keitel continued his service with the Reichswehr in various command positions. On February 1, 1925, he was transferred to General Staff Service in the Armed Forces Office, Depart-

1. Walter Goerlitz (ed.), Generalfeldmarschall Keitel: Verbrecher oder Offizier? Erinnerungen, Briefe, Dokumente des Chefs OKW (Goettingen: Musterschmidt Verlag, 1961), p. 13.

2. Ibid., p. 14; Douglas M. Kelly, Prison Psychiatrist at Nuremberg, and G. M. Gilbert, Prison Psychologist at Nuremberg, respectively referred to Keitel as "a traditional Prussian gentleman" and the "chief representative of Prussian militarism." See Douglas M. Kelley, M. D., 22 Cells in Nuremberg (New York: MacFadden Publications, Inc., 1961), p. 94; G. M. Gilbert, Nuremberg Diary (New York: The New American Library of World Literature, Inc., 1961 ), p. 29.

3. Goerlitz, Keitel, p. 19.

4. Postcard from Wilhelm Keitel to his father, March 11, 1915, ibid., p. 29.

5. Letter from Wilhelm Keitel to his father, July 13, 1915, ibid., p. 32.

6. Letter from Wilhelm Keitel to his father-in-law, December 10, 1918, ibid., p. 36. 
ment of Army Organization. ${ }^{7}$ Although his letters during that time were mostly concerned with his work, they contained some political sentiment: the writer blamed the Social Democratic Party for the financial restrictions under which the Reichswehr operated, ${ }^{8}$ and, jealous of the prerogatives of the Army, he wrote of the "presumptuous attitude of the SA." 9 Taken as a whole, however, his correspondence between the end of World War I and Hitler's chancellorship gave no hint of any interest in the National Socialist movement. The image of Keitel reflected in these letters was that of an extremely conscientious and hard-working bureaucrat. ${ }^{10}$

In November, 1931, two years after he had become head of the Organizations Department in the Armed Forces Office, Keitel was promoted to Colonel. ${ }^{11}$ Between 1933 and 1934 he served as Infantry Commander in Potsdam. During that time he had several clashes with the local SA leader, Obergruppenfuehrer Otto Ernst, whom he suspected of meddling in Reichswehr affairs. After a short period of service in Bremen, he was appointed successor to General Walther von Reichenau, the head of the Armed Forces Office. In his memoirs Keitel emphasized that it was von Fritsch who suggested him for that position, ostensibly to show that von Fritsch considered him to be a traditional soldier in contrast to the well-known National Socialist Reichenau. Although Keitel said that he was happy as Divisional Commander in Bremen and that he wanted to have nothing to do with politics, he agreed to take the new position, "because I was a bit vain and it [the appointment] was an obvious recognition of my abilities and the confidence placed in me." In 1945 Keitel wrote that when Hitler came to power, he thought of him as being a good "drummer," i.e., a man who had been successful influencing the masses of the people. "After all . . . we were used to changes in the government," he said. ${ }^{12}$ That he was not particularly bothered by some of the methods the Nazis used to come to power was not out of the ordinary for a member of his profession.

It should also be noted that Hitler's program contained promises to the Reichswehr which no patriotic officer could afford to reject without being called a traitor to his class. Former Vice-Admiral Kurt Assmann recalled later, "The officers viewed with genuine satisfaction Hitler's new program of freeing the Wehrmacht from

7. Letter from Wilhelm Keitel to his father, January 1, 1925, ibid., p. 39.

8. Letter from Wilhelm Keitel to his father, September 5, 1931, ibid., p. 47.

9. Letter from Wilhelm Keitel to his father, August 28, 1932, ibid., p. 51.

10. Letter from Lisa Keitel to father-in-law, January 23, 1926, ibid., p. 40.

11. Robert J. O'Neill, The German Army and the Nazi Party 1933-1939 (New York: James H. Heineman, Inc., 1966), Appendix B, p. 193.

12. “Memoirs 1933-1938," Goerlitz, Keitel, pp. 58-80, 79, n. 84. 
the fetters of the Treaty of Versailles and making it once again a power corresponding to the greatness of the Reich." If, from the viewpoint of a quarter century later, the officers' lack of resistance to Hitler was decried as default of character, one must also recall that the Reichswehr had for years been taught to follow von Seeckt's principle of Ueberparteilichkeit as well as his idea that it was the function of the Army to provide the strongest support for the government in power. ${ }^{13}$

The degree to which Keitel was an adherent of this kind of thinking was evident in his reflection on the Roehm Purge. He had been suspicious of the SA since his days at Potsdam and apparently believed, then and at Nuremberg, that Roehm intended to eliminate von Blomberg and von Fritsch. He regretted that General Kurt von Schleicher and Major General Kurt von Bredow had been murdered by an SA squad during the Roehm Purge; they should have been court-martialled, he said, because of their involvement in politics which were in opposition to the government in power. "General von Schleicher," Keitel wrote in 1945, "was unfortunately involved in this game; he was and remained the cat which could not resist catching political mice." ${ }^{14}$ To Keitel the entire Roehm affair was simply a matter of the legitimate government maintaining itself against a band of revolutionaries. His position, like that of the Reichswehr, was clear: support the legitimate government against disorder. There is no evidence that ideological considerations played a role in Keitel's position.

The political and military development in the first five years of Hitler's chancellorship had little effect on the structure of the Armed Forces leadership. The ascendancy of the already existing High Command of the Armed Forces (Oberkommando der Wehrmacht or OKW) on February 4, 1938, to the position which it heldat least in theory-until the end of the war was in part made possible by the dismissal of the Reich War Minister and Commander in Chief of the Armed Forces General Field Marshal von Blomberg. From now on [read the Fuehrer's decree of February 4, 1938], I exercise the immediate command over the whole armed forces. The former Wehrmacht Office in the War Ministry becomes the High Command of the Armed Forces [OKW], and comes immediately under my command as my military staff. At the head of the Staff of the High Command stands the former Chief of the Wehrmacht Office [Keitel]. He is accorded the rank equivalent to that of Reich Minister. The High Command of the Armed Forces also takes over the functions of the War Ministry, and the Chief of the High Command exercises, as

\footnotetext{
13. Vice Admiral Kurt Assmann, "Hitler and the German Officer Corps," trans. Captain Roland E. Krause. United States Naval Institute, Proceedings, LXXX (May,
1956), 510.

14. Goerlitz, Keitel, pp. 70-71.
} 
my deputy, the power hitherto held by the Reich War Minister. The task of preparing the unified defense of the Reich in all fields in accordance with my instructions is the function of the High Command in times of peace. ${ }^{15}$

The ambiguous wording of the decree, which in one place defines the OKW as "my military staff" but in another place assigns to it the role of the former War Ministry, raises the important question of how much independence of action the OKW was to possess and consequently to what degree it was to be responsible for orders issued in its name. In a conversation with the Chief of the Reich Chancellery, Dr. Hans Heinrich Lammers, Hitler explained: "In the future I do not want a Reich War Minister nor do I want a Commander in Chief of the Armed Forces who stands between myself and the Commanders in Chief of the Services." 16 The text of the Fuehrer Decree as well as Keitel's later testimony at Nuremberg indicates that the position of Reich War Minister was in fact

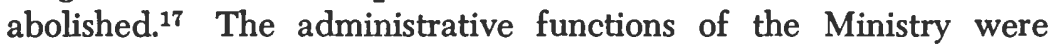
from now on handled by the OKW, whereas the command functions connected with the office of Reich War Minister in the latter's capacity as Commander in Chief of the Armed Forces were taken over by Hitler. ${ }^{18}$

Although the decree of February 4, 1938, defined the function of the OKW as a military staff of the Supreme Commander, it did not define the function of the staff, i.e., it did not explain whether the OKW was to be an advisory body to the Supreme Commander or whether it was to be a type of General Staff of the Armed Forces. When Hitler was confronted with this question, he gave an evasive answer, saying that at the "appropriate time" he would see no obstacle to a General Staff of the Armed Forces. ${ }^{19}$ The possibility of creating an Armed Forces General Staff had in fact been a matter of some controversy among the leadership of the Armed Forces since 1933. ${ }^{20}$

When von Blomberg decided in 1935 that his title "Reich Minister for War and Commander in Chief of the Wehrmacht" necessitated the creation of a High Command for the purpose of unifying the

15. Erlass ueber die Fuehrung der Wehrmacht of February 4, 1938, by Hitler, cited in Max Domarus (ed.), Hitler: Reden und Proklamationen, Vol. I: Triumph (2 vols.; Muenchen: Sueddeutscher Verlag, 1965), 782. Beginning in February, 1934, the Ministeramt in the Defense Ministry was designated Wehrmachtamt or Armed Forces Office. In cases where this office represented the Commander in Chief of the Armed Forces it used the title OKW. See Walter Warlimont, Inside Hitler's Headquarters 1939-1945, trans. R. H. Barry (New York: Frederick A. Praeger, 1965 ), p. 588.

16. Testimony of Dr. Hans Heinrich Lammers on April 8, 1946, IMT, XI, 29.

17. Deposition by Wilhelm Keitel on August 15, 1945, (Nelte File), cited in Goerlitz, Keitel, pp. 312-322.

18. John W. Wheeler-Bennett's contention that Hitler assumed the functions of War Minister is misleading. See Wheeler-Bennett, The Nemesis of Power: The German Army in Politics 1918-1945 (2d ed.; London: Macmillan \& Co., Ltd., 1964), p. 373.

19. "Memoirs 1933-1938," Goerlitz, Keitel, p. 113.

20. O'Neill, The German Army, p. 108. 
three branches of the Armed Forces along the lines of the Reich's centralized system of government, the Commanders in Chief of the Services, especially of the Army, soon expressed their opposition to his plans. ${ }^{21}$ As early as 1934 von Blomberg had begun to expand the Ministeramt in the Defense Ministry by adding an Operational Defense Staff. This development seemed to point towards a situation in which the Commanders in Chief of the Services not only would be removed to a lower level in the military hierarchy but would also have to give up part of their independent authority to von Blomberg's Ministeramt. The opponents in the struggle between the Armed Forces Office (the former Ministeramt) and the General Staff of the Army were Major General Walther von Reichenau and General Ludwig Beck respectively. After von Reichenau's transfer to the command of Wehrkreis VII, in August, 1935, Major General Keitel took his place. ${ }^{22}$

In August, 1937, von Fritsch presented von Blomberg with a lengthy memorandum in which he explained his views on the command structure of the Armed Forces. Although he recognized the need for a unified High Command of the Armed Forces, he rejected the notion that such an agency should be based upon the idea of equal importance of the three services. He argued that any organization of the High Command would have to consider the primacy of the Army in view of its greater numerical strength and its greater tactical significance in a European land war. It was for that reason unthinkable to him to interpolate an inter-service staff with coordinating functions between the Army High Command and the Commander in Chief of the Armed Forces. His major objection to a creation of an Armed Forces High Command was that such an agency would tend to mushroom into a huge bureaucracy, thus removing the influence of Army commanders from the overall direction of the war effort. The solution von Fritsch offered in his memorandum was to leave the entire power of command with the Reich War Minister and Commander in Chief of the Armed Forces. To bring about the necessary coordination between the Services, von Fritsch simply suggested that the High Command of the Army be entrusted with planning and working out the proposals for the overall conduct of the military operations. ${ }^{23}$ This solution would have given the Army General Staff the decisive voice in the planning and conduct of war. Blomberg's proposed reorganization, on the other hand, tended to concentrate planning and

21. Warlimont, Inside Hitler's Headquarters, p. 7.

22. O'Neill, The German Army, p. 108.

23. Memorandum of Colonel General von Fritsch, "Wehrmachtspitzengliederung und Fuehrung der Wehrmacht im Kriege," August, 1937, cited in Goerlitz, Keitel, pp. 123-144. 
strategy at a level which was considerably closer to the political arena than the General Staff of the Army.

According to Keitel, who maintained good personal relations with von Fritsch, ${ }^{24}$ the Commander in Chief of the Army insisted that the Army remain "above politics," since he considered National Socialism a temporary political stage and secretly nurtured dreams of a restoration of the Hohenzollern monarchy; he had welcomed Hitler as Chancellor to destroy the parties of the Weimar Republic but rejected him as Head of State. ${ }^{25}$ Von Blomberg, on the other hand, was of the opinion that the Armed Forces needed to accept the National Socialist ideology as the basis of the new state just as they had accepted the idea of the monarchy under the last emperor. "He [von Blomberg] saw in National Socialism and the Fuehrer idea a type of elective monarchy instead of the inherited monarchy." 26 The difference of opinion between those favoring the eventual creation of an all-embracing Armed Forces General Staff and those favoring von Fritsch's solution appears to have created another division within the senior officers-"revolutionary Nazi upstarts on one side and the Army traditionalists on the other," as one conservative observer put it after the war. ${ }^{27}$

However, Hitler's assumption of direct command over the Armed Forces officially eliminated the intermediary level, meaning von Blomberg and his OKW. A High Command reappeared in its place but now as Hitler's military staff. The ambiguity of Hitler's position at the time made it difficult to tell whether this new OKW was to follow the course charted for it by von Blomberg or whether it had in fact become something entirely new.

Shortly after the official announcement of the formation of the new OKW, Keitel prepared a Position Paper in which he outlined his concept of the higher organization of the Wehrmacht. $\mathrm{He}$ argued that the demands of the total war of the future necessitated a coordination of the nation's entire resources and potentialities with the purpose of incorporating them into the overall planning of the war. This total coordination, Keitel argued, could not possibly be handled by the Supreme Commander alone but must be administered by the OKW. He admitted that the Army could well be the decisive factor in a land war but added that the relative importance of the three Services was by no means fixed. Keitel appealed to the Services to consider themselvs a part of the entire

\footnotetext{
24. "Memoirs 1933-1938," ibid., p. 86.

25. Ibid., pp. 86-87.

26. Ibid., p. 86 .

27. Warlimont, Inside Hitler's Headquarters, p. 9.
} 
armed force of the nation and to surrender a part of their traditional independence of action so that unity in organization as well as in leadership would be guaranteed. ${ }^{28}$

Keitel explained later that it had been his intention to separate the command functions from the administrative functions within the existing structure at the top level of the Armed Forces. The purpose of this separation would have been to provide the Commander in Chief in his capacity as the highest ranking officer with an OKW and in his capacity as Reich War Minister with a type of ministerial office. Keitel envisioned his own position as that of the Minister's Secretary. ${ }^{29}$

Keitel's Position Paper of April 19, 1938, indicated that his thinking on the new OKW was guided solely by the desire to bring about a greater degree of efficiency in the organization of the Armed Forces. "It is contrary to the principles of total war of the future," he wrote, "to believe that the task of conducting the actual war, the coordination of economic and propaganda warfare, and the organization of the entire nation for the support of the war can be separated. They have to be very closely united, not only in the person of the Generalissimus [Commander in Chief of the Armed Forces] who would only be a shadow leader like the emperor . . . but in a staff-the High Command of the Armed Forces." 30 Keitel envisioned the organization of the Armed Forces leadership in times of war as follows: the political leadership and the leadership of the nation as a whole to be the task of the Fuehrer; the conduct of the actual warfare, the coordination of propaganda and economic measures with the goals of military operations to be the task of the Generalissimus in accordance with directions received by the Fuehrer. ${ }^{31}$

The contention that the "creation of the OKW under Keitel was a powerful means of transferring the strategic direction of German policy from the hands of the Army to those of Hitler, by default of character on the part of Keitel" 32 seems to ignore the fact that Keitel's proposed organization clearly provided for a separation of the functions of Commander in Chief of the Armed Forces from that of the Fuehrer. Keitel apparently did not realize at that time that Hitler never intended to fill the position of Commander in Chief of the Armed Forces and that Hitler's solution constituted an amal-

\footnotetext{
28. Position Paper by the Chief of the OKW, "Die Kriegsfuehrung als Problem der Organization," April 19, 1938, cited in Goerlitz, Keitel, pp. 154-164.

29. "Memoirs 1933-1938," ibid., p. 98.

30. Position Paper by the Chief of the OKW, "Die Kriegsfuehrung als Problem der Organisation," April 19, 1938, ibid., p. 155.

31. Ibid., p. 154.

32. O'Neill, The German Army, p. 117.
} 
gamation of the political and military leadership. All that remained of Keitel's plan of organization was the hope that the unified command of three Services had been institutionalized in the OKW. ${ }^{33}$

The circumstances surrounding Keitel's appointment as head of this ill-defined organization have been the subject of some disagreement. It has been argued that Keitel had in fact worked towards achieving this position for himself. A closer examination of Keitel's appointment, however, shows that he neither wanted the position nor knew what it entailed after he had accepted it. In fact, he does not seem to have become aware of the impending removal of von Blomberg until January 26, 1938. It was in the course of a conversation on that date that von Blomberg told Keitel to report to Hitler on that afternoon. At five o'clock Keitel presented himself to Hitler, whom he had personally never met before. Hitler indicated to Keitel that he was deeply hurt by the entire Blomberg affair but that he had, nevertheless, given the new couple a trip around the world. He then brought up the question of a successor to von Blomberg; Keitel mentioned Hermann Goering. After Hitler rejected that proposal, Keitel suggested von Fritsch. At this point Hitler informed Keitel of the pending charges against the Colonel General. Shocked by the distressing news, Keitel continued to make suggestions: Colonel General Gerd von Rundstedt was rejected because of his advanced age, General Walther von Brauchitsch was discussed but nothing was decided. Keitel was ordered to report again on the following day. ${ }^{34}$

When Keitel met Hitler on January 27, Hitler seemed extremely upset. He informed Keitel of the latest developments in the Fritsch affair and fulminated against his adjutant, Colonel Friedrich Hossbach, who had informed Fritsch of the charges against him. When Keitel again suggested Goering as successor to von Blomberg, Hitler suddenly told him that he had decided to take personal command of the Armed Forces and that he had chosen him, Keitel, to be his Chief of Staff; Keitel agreed "without hesitation." ${ }^{35}$ That the turbulent events of the last days of January must have greatly disturbed Keitel is shown in the entries in General Jodl's diary. After his first meeting with Hitler, Keitel came to Jodl "deeply shaken with tears in his eyes about the tremendous blow dealt to our joint task. I say to him: even if the man [Blomberg] should

33. By June, 1938, the OKW consisted of four major departments: an Armed Forces Operations Office or Wehrmachtfuehrungsamt, a Foreign and Counter Intelligence Office or Amt Ausland/Abwehr, a General Armed Forces Office or Amtsgruppe Allgemeine Wehrmachtsangelegenheiten, and a Military Economics Group or Wirtschafts und Ruestungsamt.

See H. R. Trevor-Roper (ed.), Blitzkrieg to Defeat: Hitler's War Directives 1939-1945 (New York: Holt, Rinehart and Winston, 1965), p. xviii.

34. Goerlitz, Keitel, pp. 87, n. 117, 106-109.

35. Ibid., p. 109. 
fall, his work must remain alive." The entries of January 27 indicate not only the type of emotional pressure which Hitler brought to bear on Keitel but also the very close identification which Keitel and Jodl felt with the organizational accomplishments of von Blomberg: "He [Hitler] says to Keitel, I am now relying on you, you must stay with me. You are my confidant and only adviser in military questions. The unified leadership is sacrosanct and invoilable to me. . . . General Keitel says to me: the unity of the Wehrmacht is secured." During that conversation Hitler also complained to Keitel about his growing loneliness and his disappointments. Jodl concluded his observations of the meeting that day with the comment: "It was a tragic and deeply shocking moment . . . but all shadows are overcome by the certainty: the work of the First Fieldmarshal of the Third Reich, the unity of the Wehrmacht and its leadership, lives and if a kind fate stays with us won't be destroyed again." ${ }^{36}$ From his jail cell in Nuremberg in 1946, Keitel wrote about the events of January, 1938, saying that he had had the time neither to reflect on the events during these hectic days nor to be aware of the type of "Trojan horse" with which he had burdened himself. ${ }^{37}$

The answer to the question why Keitel accepted the position of Chief of Staff appears to be that he felt at the time that the important thing was to maintain the unified command of the Armed Forces while at the same time he was quite obviously taken in by Hitler's emotional appeal. There is no evidence that Keitel agreed to Hitler's offer because he was a National Socialist or because he desired the position for selfish reasons. Eight years later Keitel wrote: "No man could foresee how inextricable my task would be and that I would one day become the object of Hitler's uninhibited dictatorship." 38

Rather than becoming the ministerial secretary, Keitel thus found himself in a position which required qualifications which he, by his own admittance, did not possess.39 "What they [Keitel and Jodl] obviously failed to realize was that, with Hitler's assumption of command over the Wehrmacht, the staff of OKW had lost the purely military character which it had hitherto preserved.

[It] became henceforth the 'working staff' or . . . military bureau of Hitler, the politician." 40

36. General Colonel Jodl's official diary, entry of January 26, 1938, IMT, XXVIII, 356-357; January 27, ibid., 358-359.

37. "Memoirs 1933-1938," Goerlitz, Keitel, p. 113.

38. Ibid.

39. Ibid., p. 99.

40. Warlimont, Inside Hitler's Headquarters, p. 12. 
That the OKW was hardly ever any more than a military bureau is now widely recognized. ${ }^{41}$ But at the time of the change in the structure of the Armed Forces leadership and indeed up to the end of the Trials before the International Military Tribunal, the opinion persisted that the OKW was an agency of considerably greater significance. ${ }^{42}$ Although Hitler had given Keitel assurances that he "would never take a decision affecting the Wehrmacht without first hearing the views of his Chief of Staff," 43 he made little effort to do so and gradually reduced Keitel to a position of head clerk in his military bureau. ${ }^{44}$ Just how sincere Hitler was in his promise to consult Keitel in important matters was demonstrated at the famous Berghof conference between Hitler and Chancellor Kurt von Schuschnigg on February 11, 1938. Keitel was ordered to the Berghof without receiving a reason. Upon his arrival, Keitel was informed that Hitler was going to have a talk with the Austrian Chancellor in order to clear up some difficulties between the two governments and that he wanted some generals present to "impress" Schuschnigg. The generals were not asked to participate in nor did they know the precise object of the conferences. ${ }^{45}$ During a pause in the afternoon session Schuschnigg left the conference room to consult with another Austrian official. When Hitler suddenly began to shout for Keitel, the General presented himself and asked for orders. Hitler merely grinned and replied: "There are no orders. I just wanted you here." 46 Keitel realized his function then, namely to play a part in Hitler's attempt to intimidate the Austrian Chancellor. Neither in this instance nor in the case of Germany's march into Austria in March, 1938, was Keitel consulted. In the latter case he was ordered to prepare for possible military intervention two days before the beginning of the campaign. ${ }^{47}$

Hitler's reasons for selecting Keitel as Chief of the OKW sheds some interesting light on his true intentions in relation to the OKW and Keitel's functions within that body. Field Marshal von Blomberg said at Nuremberg that he discussed the question of his successor with Hitler during his last visit to the Chancellery. Von Blomberg was apparently hesitant to name a successor when Hitler

41. Percy Ernst Schramm, Hitler als militaerischer Fuehrer: Erkenntnisse und Erfahrungen aus dem Kriegstagebuch des Oberkommandos der Wehrmacht (2d ed. rev.; Frankfurt am Main: Athenaeum Verlag, 1965), p. 163.

42. Appendix B of Indictment, Statement of Criminality of Groups and Organizations, IMT, I, 83-84.

43. Warlimont, Inside Hitler's Headquarters, p. 14.

44. B. H. Liddell Hart, The German Generals Talk (New York: William Morrow \& Co., 1948 ), p. 88.

45. "Memoirs 1938-1945," Goerlitz, Keitel, p. 117.

46. Franz von Papen, Memoirs, trans. Brian Connell (London: Andre Deutsch, 1952), p. 417 .

47. “Memoirs, 1938-1945," Goerlitz, Keitel, p. 178. 
suddenly asked him for the name of "that general who's been in your office up to now?' Von Blomberg replied: 'Oh, Keitel; there's no question of him; he's nothing but the man who runs my office.' Seizing on this straight away, Hitler said at once: 'That's exactly the man I'm looking for.' " 48

Hitler knew little of the man he wanted to succeed von Blomberg. Considering the fact that Hitler apparently agreed to an unknown man as successor to the highest military post in the nation, an unkown man in whose political attitudes he was not interested and of whose other qualifications he had just received an estimate that he was hardly suitable for the position, it seems reasonable to say that Hitler looked upon Keitel as either a stop-gap appointment or a figurehead. His subsequent performance before Keitel seems to have been put on for the purpose of instilling confidence in Keitel and leading him to believe that he intended to carry through Blomberg's reforms.

The significance of the events of February 4, 1938, can hardly be overestimated. The German public was never informed of the true reasons for the dismissals of von Blomberg and von Fritsch. An official communique mentioned only that certain changes in personnel had taken place. ${ }^{49}$ The Voelkischer Beobachter spoke at length about the significance of the events. It emphasized that the changes in personnel were not accidental but the "visible expression of an organized and planned development." The paper interpreted the changes in command by saying, "The process of amalmagation between Army and Party is taking now a clearer organizational form. It is becoming increasingly clear that the leadership principle of the National Socialist state in its political and military character goes back to a single military source of power." 50 Hermann Goering's promotion to General Field Marshal was seen as a symbolic act; "it represented the betrothal of the soldierly spirit of the National Socialist movement to its political will." 51

At the same time, the Army paper Wehrmacht commented on the events of February 4 in a considerably less enthusiastic manner. This paper merely pointed out that the changes in the structure of the Wehrmacht leadership served to simplify the existing "organiza-

\footnotetext{
48. Warlimont, Inside Hitler's Headquarters, p. 13; Affidavit by von Blomberg on February 16, 1946, IMT, XL, 407-408.

49. Hermann Mau and Helmut Krausnick, Deutsche Geschichte der iuengsten Vergangenheit 1933-1945 (Tuebingen: Rainer Wunderlich Verlag Herman Leins; Stuttgart: J. B. Metzlersche Verlagsbuchhandlung, 1964), p. 62.

50. Hermann Foertsch, Schuld und Verhaengnis: Die Fritsch-Krise im Fruehiahr 1938 als Wendepunkt in der Geschichte der Nationalsozialistischen Zeit (Stuttgart: Deutsche Verlagsantalt, 1951), p. 109.

51. Ibid., p. 110.
} 
tional monstrosity" and mentioned Keitel as the first adviser of Hitler in questions relating to the unified preparation for defense. "There is no doubt," the paper said, "that next to the organizational simplification, the whole Wehrmatch is closer to Hitler. He is now, without an intermediary agency, the Supreme Commander." 52

The military leaders in their political naiveté saw in the events of February 4, 1938, little more than a solution to an organizational problem. The more astute political leaders, however, realized that the integration of the Armed Forces into the totality of the Third Reich was well on its way. These differences in interpretation are an indication of the ambiguity of Keitel's position.

52. Ibid., pp. 111-112. 


\section{Chapter IV}

\section{The Traditional Soldier in the Totalitarian State}

In the course of the Trial of the Major War Criminals before the International Military Tribunal at Nuremberg, Germany, the defense counsel for Keitel, Dr. Otto Nelte, submitted a chart which showed the OKW in the form of a pyramid:

The

FUEHRER

as

SUPREME COMMANDER OF THE

Armed Forces

with the military staff.

"HIGH COMMAND OF THE ARMED FORCES"

(heading the staff)

Chief of the High Command of the Armed Forces

Keitel.

The base of the pyramid showed eleven different offices representing the various agencies of the High Command. ${ }^{1}$ In an affidavit submitted by the defense to the Tribunal, Keitel explained that the OKW was the highest administrative office for the Armed Forces but that for operational and strategic matters, the OKW maintained only a few offices such as the Armed Forces Leadership Staff and the Foreign and Counter Intelligence Office whose services were used by the three branches of the Armed Forces. On the other hand, the OKW used the specialized departments of the Services either to work out the details of plans which, in their rough outlines, had been suggested to them by Hitler through the OKW or to transmit plans and suggestions of the Services to Hitler. The problem with this arrangement, Keitel pointed out, was that the Services found ways to circumvent the OKW and to win Hitler's approval of proposals of which the OKW had no prior knowledge. Under these conditions it is not surprising that Keitel found it extremely difficult to maintain the authority of his office. Keitel further testified that because of conflicting demands by the three branches of the Services, he found himself in the unwelcome position of a

1. Document Keitel-1 (a), IMT, XL, 350-351. 
mediator. A third factor complicating his position was Hitler's unwillingness to adhere to orderly procedures as well as his habit of spontaneous intervention in strategic and administrative matters. ${ }^{2}$

Keitel's testimony at Nuremberg stood in sharp contrast to his rank of Generalfeldmarschall and Chief of the OKW: he could hardly be called Hitler's first adviser. One former member of the OKW went so far as saying that the entire OKW had "no authority other than that which Hitler was occasionally willing to lend it." 3 Other witnesses who were familiar with the situation within the OKW testified to the fact that Keitel's influence on the formulation of orders was insignificant and that his powers were extremely limited. ${ }^{4}$ But not everyone testified in this manner. In the testimony of Dr. Hans Bernd Gisevius, former Gestapo officer and wartime OSS (Office of Strategic Services) collaborator, ${ }^{5}$ Keitel was characterized as one of the most influential men in the Third Reich and as a man who exerted great influence on the Armed Forces. However, this testimony was thoroughly discredited during the trial. ${ }^{6}$ In substance, the Keitel affidavit seems to be correct.

Perhaps because of the discrepancy between his high rank and his limited responsibilities, Keitel has fared poorly at the hands of historians. To Trevor-Roper he was a "compliant puppet," to Telford Taylor a "doormat," to Gordon Craig a "man of no character and thorough going admirer of Hitler," and to Wheeler-Bennett a man "of complete acquiescence and subservient adulation." 7 Judgments of this sort, however, are difficult to substantiate.

Central to an understanding of Keitel's actions is his concept of duty and loyalty, which was the product of a lifetime in military service. In spite of the fact that Hitler did not appoint a Generalissimus and soon began to make a shambles of the kind of OKW for which Keitel had worked, the General stayed on. General Walter Warlimont observed that "he was honestly convinced that his appointment required him to identify himself with the wishes and

2. Affidavit by Wilhelm Keitel of March 8, 1946, ibid., 355-361.

3. Walter Warlimont, Inside Hitler's Headquarters 1939-1945, trans. by R. H. Barry (New York: Frederick A. Praeger, 1965), p. 17.

4. General Siegfried Westphal, The German Army in the West (London: Cassell and Company, Ltd., 1951), p. 46; Statement by Vice-Admiral L. Buerckner on June 28, 1946, IMT, XL, 417.

5. Eugene Davidson, The Trial of the Germans: An Account of the twenty-two defendants before the International Military Tribunal at Nuremberg (New York: The Macmillan Company, 1966 ), p. 69.

6. Statement by Vice-Admiral L. Buerckner on June 28, 1946, IMT, XL, 417-418; Office of United States Chief Counsel for Prosecution of Axis Criminality, Nazi Conspiracy and Aggression, Supplement B, Final Argument by Dr. Otto Nelte ( 8 vols. and 2 supplementary vols. A and B; Washington: U. S. Government Printing Office, 1946), p. 242.

7. H. R. Trevor-Roper, The Last Days of Hitler (New York: The Macmillan Co., 1947), p. 122; Telford Taylor, The March of Conquest: The German Victories in Western Europe, 1940 (New York: Simon and Schuster, 1958), p. 13; Gordon A. Craig, The Politics of the Prussian Army 1640-1945 (New York: Oxford University Press, 1964). p. 495; John W. Wheeler-Bennett, The Nemesis of Power: The German Army in Politics 1918-1945 (2d ed.; London: Macmillan \& Co. Ltd., 1964), p. 429. 
instructions of his Supreme Commander, even though he might not personally agree with them, and to represent them faithfully to all those involved." 8 Although Keitel's relations with Hitler prior to the war with the Soviet Union seem to have been relatively free of friction, there were several incidents which indicated that Keitel was not convinced-at least not then-that he was to act only as Hitler's mouthpiece.

The first of these incidents occurred in connection with the proposed attack on France. Hitler's Directive No. 6 for the Conduct of the War of October 9, 1939, requested the Commanders in Chief of the three Services to submit detailed plans for an attack in the West. ${ }^{9}$ Opposition to such an attack on France at this time was strong within the Armed Forces, and Keitel, who shared the view of that opposition, went to Hitler on November 4 to present the Army's case. Hitler accused him of obstructionism and of participation in a generals' conspiracy against him. "He demanded of me," Keitel wrote, "that I accept his views and represent them without reservations to the High Command of the Army (OKW)." 10 Keitel was deeply hurt, primarily, because Hitler doubted the quality in himself of which he was most proud: his loyalty as a soldier. $\mathrm{He}$ took the consequences of Hitler's accusations and asked for his dismissal. A second conference followed in which Hitler told Keitel that he rejected his request, that he furthermore did not wish to receive such requests, and that it was Keitel's duty to do his job in the position in which he, Hitler, had placed him. ${ }^{11}$ General Walther von Brauchitsch offered his opposition to Hitler's planned attack in the West in the same manner on November 23, 1939. He received a similar dressing down and offered his resignation which was subsequently rejected. ${ }^{12}$

This incident was by no means the last clash between the Fuehrer and his Chief of the OKW. When Hitler decided to entrust Gauleiter (Party District Leader) Josef Terboven with the administration of the occupied Norwegian territory, Keitel again protested and received another dressing down in front of the assembled officers at the daily situation conference. A second attempt to place the administration of Norway in the hands of the Wehrmacht also failed. ${ }^{13}$

8. Warlimont, Inside Hitler's Headquarters, p. 13.

9. H. R. Trevor-Roper (ed.), Blitzkrieg to Defeat: Hitler's War Directives 1939-1945 (New York: Holt, Rinehart and Winston, 1965), pp. 13-14.

10. "Memoirs 1938-1945," Walter Goerlitz (ed.), Generalfeldmarschall Keitel: Verbrecher oder Offizier? Erinnerungen, Briefe, Dokumente des Chefs OKW (Goettingen: Musterschmidt Verlag, 1981), p. 223.

11. Ibid., p. 224.

12. Testimony by von Brauchitsch on August 9, 1946, IMT, XX, 575 .

13. “Memoirs 1938-1945," Goerlitz, Keitel, p. 230. 
Another area of disagreement was over the role of Heinrich Himmler's police force in the occupied areas. The OKW protested vigorously against the arrival of Himmler's police detachments in the occupied areas of Poland. Nothing could be done to prevent it, since Hitler, who had already given his consent to Himmler, was not to be swayed. Consequently during the planning for the attack on the West, the OKW, having learned its lesson from Poland, took steps to keep Himmler's police out of France. Hitler gave his consent to keep out Himmler's men, but Himmler managed to circumvent the restrictions of the OKW and created a special unit under the command of the notorious Reinhard Heydrich: disguised in field-gray Army uniforms and riding in vehicles with military license plates provided by Himmler, Heydrich's detachment reached Paris. ${ }^{14}$ In the light of these clashes between Keitel and Hitler, WheelerBennett's contention that "there is no evidence that Keitel ever uttered the remotest query to a single decision of the Fuehrer" is without historical foundation. ${ }^{15}$

In spite of his difficulties with Hitler, Keitel managed to continue his assigned job. He admired Hitler's military abilities-things had gone well so far-and he considered the conclusion of the armistice with France as the zenith of his military career. The victory over France was to Keitel "the hour of retaliation for Versailles, a sensation mixed with the proud awareness of a unique campaign and the promise to honor and protect the soldierly honor of the vanquished." He was pleased about his promotion to Generalfeldmarschall, but he said that he was somewhat ashamed at the same time: in his opinion this distinction should have been reserved for field commanders only. ${ }^{16}$

What Keitel admired in Hitler in the years before the war against the Soviet Union was the military leader, the strong head of state, and the man who had helped restore the strength of the Armed Forces. Perhaps his judgment of Hitler's military abilities was due to his limited understanding of strategy. On the other hand, some military historians argue that Hitler was "one of the most knowledgeable and diversified military-technical specialists of his time." 17 Keitel's opposition to measures based upon ideological considerations, such as the appointment of Gauleiter Terboven or the use of

\footnotetext{
14. Jacques Delarue, The Gestapo: A History of Horror, trans. by Mervyn Savill (New York: Dell Publishing Co., Inc., 1965), pp. 232-233.

15. Wheeler-Bennett, The Nemesis of Power, p. 429.

16. "Memoirs 1938-1945," Goerlitz, Keitel, pp. 235-238.

17. Helmut Heiber (ed.), Lagebesprechungen im Fuehrerhauptquartier: Protokollfragmente aus Hitlers militaerischen Konferenzen 1942-1945 (Muenchen: Deutscher Taschenbuch Verlag G. m. b. H. \& Co. KG, 1963), p. 23; Percy Ernst Schramm, Hitler als militaerischer Fuehrer: Erkenntnisse und Erfahrungen aus dem Kriegstagebuch des Oberkommandos der Wehrmacht (2d ed. rev.; Frankfurt am Main: Athenaeum Verlag, 1965), pp. 57-58.
} 
SS Commandos ${ }^{18}$ behind the front lines, shows that he had kept himself relatively free of the ideology of the movement. The honors and distinctions which he received were awarded to him by a grateful Hitler for loyalty and devotion to his work.

General Field Marshal von Blomberg testified at Nuremberg that "it is general knowledge that Hitler kept Keitel at his side because he was convinced of his unconditional soldierly obedience and loyalty." 19 General Jodl called him "an obedient and dutyful soldier, too soft and too decent for Hitler-but upright, truthful and helpful." 20 Another analysis of Keitel's character was offered by Colonel General Franz Halder. It was more detailed and less colored by years of friendly relations than Jodl's: "He was extremely industrious, literally a work animal, extremely conscientious in his field, but in all he did he kept his personality out of it. . . . Originally, and I can vouch for it, he was by no means blind to the danger of Hitler. He fought persistently-persistently, but not energetically enough against the growth of the SS." 21

Jodl, who worked closest with Keitel and perhaps knew him best, also testified of many instances when Keitel opposed Hitler. "But when Hitler then became rude and abusive, so that one had to be embarrassed because of the junior officers present, he resigned himself and avoided anything that could lead to such depressing scenes. He took flight into his work." ${ }^{22}$ One such incident which perhaps best describes the kind of humiliation to which those in the Fuehrer's environment were exposed was related by Halder: "I can still hear Hitler's tone: 'Hey, Field Marshal!' I asked Keitel about that later. He broke down and declared with tears in his eyes: 'Halder, I am doing it for you [the Army]! Don't you understand?' This indicates the path which brought him in connection with criminal things-but a wicked man, as one would read at timesthat he was not." 23

Keitel himself offered evidence of his devotion to duty, not ideology. Throughout his memoirs, letters, and testimony, he stressed the point that his actions were guided by his sworn duty to the Supreme Commander. "We understood our task to assist Hitler in operative matters ordered and planned by him without having anything to do with the political motives for these actions.

18. The SS (Schutzstaffeln) consisted of certain military and police formations which were under the command of Heinrich Himmler.

19. Affidavit by von Blomberg on February 26, 1946, IMT XL, 409.

20. Affidavit by Jodl on June 17, 1946, ibid., 422.

21. Peter Bor, Gespraeche mit Halder (Wiesbaden: Limes Verlag, 1950), p. 115.

22. Affidavit by Jodl on June 17, 1946, IMT, XL, 421.

23. Peter Bor, Gespraeche mit Halder, p. 116. 
We were not asked to concern ourselves with them." 24 Although Keitel admitted that certain elements in Hitler's program contributed greatly to the "soldierly education," he emphasized that this meant by no means that he accepted the entire program of the National Socialist Party. ${ }^{25}$ This sentiment was a familiar one: the officer remains above politics and accepts only those points in the political program of the government which serve his class interests. The fact that Keitel maintained this attitude to the very end indicates not only that he was unable to rid himself of the traditional view of the Army's role in the state but also that he apparently did not comprehend Hitler's role as the leader of a revolutionary movement.

Hitler's statement in 1933 that he believed in the concept of Ueberparteilichkeit for the Armed Forces ${ }^{26}$ had-at least in theory -become meaningless by February 4, 1938, when he had merged his political office with the office of Supreme Commander. In a speech to the graduating Officer's Class of 1938, Hitler returned to his old theme of creating a new and select class of politically and racially suitable leaders. ${ }^{27}$ In the fall of 1939 , he told his military commanders that the "creation of the Wehrmacht was possible only in connection with the ideological education of the people through the Party." 28

A study of the Constitution of the Armed Forces reveals the extent to which the Armed Forces had become gleichgeschaltet: "The office of the Fuehrer, not unlike the position of the monarch in former times, constitutes a concentration of political and military rights." The document goes on to say that the major differences between the position of the monarch and the position of Hitler lies in the fact that the monarch's basis was the army, whereas "the position in which the Fuehrer stands and from which he speaks to the people as well as to the Wehrmacht, is the position expressed by the National Socialist people's movement, the Party."

The author of the document, Johannes Heckel, admitted that there existed a "seemingly difficult" constitutional problem conp. 395 .

25. Ibid., p. 391 .

26. Speech by Hitler to the generals on February 3, 1933, in Walther Hofer (ed.). Det Nationalsozialismus: Dokumente 1933-1945 (Frankfurt am Main: Fischer Buecherei K. G., 1957 ), p. 181.

27. Hitler's "Rede vor dem Offiziersjahrgang 1938" (Speech to the entire year's class of officers) on January 25, 1939, in the Reich Chancellery, cited in Dr. Hans-Adolf Jacobsen and Dr. Werner Jochmann (eds.), Ausgewaehlte Dokumente zur Geschichte des National sozialismus 1933-1945 (Bielefeld: Neue Gesellschaft G. m. b. H., 1961), n. p. ibid.

28. Speech by Hitler on November 23, 1939, to the Commanders of the Armed Forces, 
cerning the position of this "political leader" to the Armed Forces. But he quickly offered the solution: "He [the Fuehrer] represents . . a new type of head of state. He is neither professional soldier nor civilian, but a political fighter who assembles the people as his followers around himself. . . . The power of the military command is therefore nothing but the military-technical expression of the already existing right of the Fuehrer." 29

The Constitution of the Armed Forces conceded that the "legalistic thinking of the past" would demand a guarantee for the separation of political from military power but added that "our constitutional and administrative law knows neither normative nor institutional guarantees. We do not have a guardian of the constitution. . . We have no supreme court because we have been taught by past experience that these are bound to fail. In accordance with the personalized order of our legal existence we see that guarantee in Hitler. It is his task and no one knows better than he does . . . how he must lead the Armed Forces." 30 Hitler, as Fuehrer and Supreme Commander of the Wehrmacht, could thus quite legitimately dress ideological goals in military orders and demand their execution according to principles of soldierly obedience, which derived from the general duties of the citizen. ${ }^{31}$

Keitel apparently never comprehended the implications of the Constitution of the Armed Forces as to his own position. He admitted that the Army was penetrated by National Socialist ideas, but at the same time stubbornly insisted "that we [the generals in the OKW] had nothing to do with the Party." ${ }^{32} \mathrm{He}$ fits well into the picture of the German officer which Lieutenant Fabian von Schlabrendorff, one of the active members of the resistance within the Army, drew after the war: "One of the main strengths of the German officer was his military one-sidedness. The normal German officer worked and lived in his profession. . . . But in his strength lay his weakness. His military one-sidedness made him incapable of passing judgment on anything outside his field, especially political matters." 33

\footnotetext{
29. Johannes Heckel, Wehrverfassung und Wehrrecht des Grossdeutschen Reiches, Paragraph 83, ibid.

30. Ibid.

31. Hans Buchheim, Martin Broszat, Hans-Adolf Jacobsen and Helmut Krausnick, Anatomie des SS-Staates ( 2 vols.; Olten und Freiburg im Breisgau: Walter Verlag, 1965), I, 273.

32. Memorandum by Keitel to Dr. Otto Nelte, n. d. (Nelte File), Goerlitz, Keitel, p. 391 .

33. Fabian von Schlabrendorff, Offiziere gegen Hitler (Frankfurt am Main: Fischer Buecherei K. G., 1962), p. 103.
} 
. 


\section{The Failure of an Ideology}

The year 1941, not unlike the year 1938, was to bring a new turning point in the relations between the NSDAP and the Armed Forces. France had fallen in 1940, and Hitler, after a brief Balkan interlude, turned his attention in 1941 to his ideological enemy of long standing-Communism in the USSR. In the course of that turbulent year, Hitler personally took command of the Army while the military establishment as a whole found itself drawn closer into the ideology of the movement.

On December 18, 1940, Hitler issued Directive No. 21, "Case Barbarossa": "The German Armed Forces must be prepared, even before the conclusion of the war against England, to crush Soviet Russia in a rapid campaign." 1 Possible military action against the Soviet Union had been the subject of a conference between Hitler and a number of top military leaders as early as July 31, 1940. ${ }^{2}$ Concerned about the lack of troops for a campaign of this magnitude, Keitel sent a memorandum to Hitler in which he warned of a possible two-front war and of the danger of American intervention. The tone and content of Hitler's reply were such that Keitel once again asked for his dismissal and transfer to the front. Hitler, as usual, rejected his request. ${ }^{3}$

The war against the Soviet Union, unlike any of the preceding campaigns, bore a very definite ideological character. According to notes made by General Halder during Hitler's speech to the military leaders on March 28, 1941, Hitler described the coming conflict as a battle of ideologies in which Communists should not be treated as soldiers: the goal of the conflict was the destruction of the Communist intelligentsia. Commissars and members of the GPU (Soviet Secret State Police), Hitler said, were criminals and must, therefore, be treated as such. ${ }^{4}$ Perhaps in anticipation of opposition from the military, he ended his speech, saying, "I do not demand

1. Directive No. 21, "Case Barbarossa," cited in H. R. Trevor-Roper (ed.), Blitzkrieg to Defeat: Hitler's War Directives 1939-1945 (New York: Holt, Rinehart and Winston, 1965 ), p. 49.

2. Walter Goerlitz (ed.), Generalfeldmarschall Keitel: Verbrecher oder Offzier? Erinnerungen, Briefe, Dokumente des Chefs OKW (Goettingen: Musterschmidt Verlag, 1961), p. 242, n. 10 .

3. "Memoirs 1938-1945," ibid., p. 244.

4. Halder diary entry of March 30,1941, cited in Max Domarus (ed.), Hitler: Reden und Proklamationen 1932-1945, Vol. II: Untergang (2 vols.; Muenchen: Sueddeutscher Verlag, 1965), 1682 . 
that the generals understand me, but I do demand that they obey my orders." 5 The ideological character of the coming war was further expressed in a series of special orders, notably the "Commissar Order." This order declared that captured Soviet officials and political Commissars would be treated as criminals and not as prisoners of war. When captured, they were to be shot on the spot or turned over to the Field Sections of the SD (Security Service). ${ }^{6}$

The actual formulation of these orders began with a Fuehrer Directive to the Reichsfuehrer SS Heinrich Himmler, which charged him with carrying out "special tasks" in the conquered areas. ${ }^{7}$ By order of Hitler, OKW then included in its Guidelines to Directive No. 21 the provision that the Reichsfuehrer SS was to perform "special tasks in preparation for the political administration [of the conquered areas]" within the operational area of the Armed Forces. ${ }^{8}$ Military actions thus became connected with purely political actions, and the Armed Forces were caught in an undertaking which was guided by racial and ideological considerations. ${ }^{9}$

Keitel's involvement in the formulation of these orders is difficult to determine. General Warlimont held that "there was only one man, Hitler, who was both officially and personally involved in the authorship and drafting . . ; his unhappy Chief of OKW was also involved but only as a recipient." 10 But in a memorandum to his defense counsel, Keitel wrote: "I do not deny that I have had knowledge of all these orders, regardless of whether I signed them or not. I do not deny that Hitler talked about them with me and Colonel General Jodl and that I transmitted them and supervised their execution." 11 Keitel claimed that he attempted to resist these orders because he was afraid that, as in Poland, Himmler would "abuse these measures to establish order behind the front." 12 At Nuremberg, Keitel admitted that he and the other generals should have resisted these orders, "but we saw only the military situation as it was; we let ourselves be guided by this as well as . . . the suggestive powers of the Fuehrer and Supreme Commander who

5. "Memoirs 1938-1945," Goerlitz, Keitel, p. 258.

6. Walter Warlimont, Inside Hitler's Headquarters 1939-1945, trans, by R. H. Barry (New York: Frederick A. Praeger, Publishers, 1965), p. 161. The SD (Sicherheitsdienst) or Security Service was an agency of the Reichsfuehrer SS and Chief of the German Police Heinrich Himmler. The function of the SD in the East was to prepare the way for the future political settlement of the conquered areas. See Alan Clark, Barbarossa: The Russian German Conflict, 1941-1945 (New York: William Morrow and Company, 1965), p. 61 .

7. Andreas Hillgruber, Hitlers Strategie: Politik und Kriegfuehrung 1940-1941 (Frankfurt am Main: Bernard \& Graefe Verlag fuer Wehrwesen, 1965), pp. 523-524.

8. Guidelines to Directive No. 21, IMT, XXVI, 54.

9. Hillgruber, Hitlers Strategie, pp. 525-526.

10. Warlimont, Inside Hitler's Headquarters, p. 170.

11. Memorandum by Keitel to Dr. Nelte, Goerlitz, Keitel, p. 395.

12. "Memoirs 1938-1945," ibid., p. 259. 
had impressed us greatly with his success in Poland and France." 13 In his final plea before the International Military Tribunal, Dr. Otto Nelte said that his client knew the criminal nature of the orders in question but that he was unable to evade them. ${ }^{14}$ Evasion under the circumstances would have meant either resignation, disobedience, or, in the extreme, suicide. Attempts to resign had proven futile in the past. At one occasion Hitler had driven Keitel to a suicide attempt, but Jodl managed to take his pistol from him in time. ${ }^{15}$ To disobey Hitler's orders, however, appears to have been unthinkable for Keitel.

The conflict with the USSR signified not only the penetration of military considerations with ideological concepts but also a new arrangement in the structure of the High Command of the Armed Forces. General Halder noted in his diary entry of December 15, 1941: "First serious discussion with the Commander in Chief [von Brauchitsch] regarding the situation; he is most depressed and sees no way out of the situation." 16 Two days later, von Brauchitsch resigned, a sick and broken man. ${ }^{17}$ The situation created by the resignation of the Commander in Chief of the Army was not unlike the one on February 4, 1938. Hitler saw an opportunity and quickly announced that thenceforth he was in personal command of the Army in the Eastern theater of war. His "Proclamation Concerning the Change in the High Command" explained in its introductory section that his assumption of the office of Commander in Chief of the Army was "the logical development" of his decree of February 4, 1938. The second part of the proclamation was addressed to the "Soldiers of the Army and the Waffen SS," and it exhorted the troops to stay firm in their "loyalty and obedience." 18

Hitler's comment to Halder on the changes of command indicated his hardly veiled contempt for the traditional work of general staff officers: "That little bit of operations work anyone can do. The job of Commander in Chief of the Army is to educate the Army in the National Socialist spirit. I don't have a single Army general who would do that job in my sense. I have therefore decided to take command of the Army myself." 19 This was one of those rare

13. Memorandum by Keitel to Dr. Nelte, ibid., p. 393.

14. Office of United States Chief Counsel for Prosecution of Axis Criminality, Nazi Conspiracy and Aggression, Supplement B, Final Argument by Dr. Otto Nelte (8 vols. and two supplementary vols. A and B; Washington: U. S. Government Printing Office, 1946), p. 242.

15. Testimony of Jodl, on June 6, 1946, IMT, XV, 440.

16. Halder diary entry of December 15, 1941, cited in Warlimont, Inside Hitler's Headquarters, p. 212.

17. "Memoirs 1938-1945," Goerlitz, Keitel, p. 286.

18. "Verlautbarung ueber den Okerkommandowechsel," cited in Domarus, Hitler, II, 1813-1814.

19. Peter Bor, Gespraeche mit Halder (Wiesbaden: Limes Verlag, 1950), pp. 214-215. 
admissions by Hitler that the Party, in spite of its clamoring about the National Socialist Wehrmacht, had failed to convert even the generals.

As a result of the changes in the command of the Army, the entire organization of the Armed Forces, which had already been unduly strained by Hitler's arbitrary methods, entered an accelerated process of disintegration from which it never recovered. General Adolf Heusinger recalled the situation: "No one is at the moment responsible for training, organization, replacements, administration. . . . Keitel is supposed to undertake the greater part of these difficult jobs, to some extent as Hitler's deputy. Soon he won't know whether he is Chief of the OKW or Deputy Commander in Chief of the Army." 20 Warlimont claims that no one ever defined which areas of competence of the Army's Commander in Chief were now to be handled by Keitel. To complicate matters even further, the responsibility of the Army High Command was restricted to the Eastern front, and as far as operations were concerned, there was no longer a unified command of the Armed Forces. Apart from Hitler, no one had any authority over all the forces of the Army and, therefore, over the reserves, and no one else could order movements of troops from one theater of war to another. ${ }^{21}$ In short, Hitler, as Supreme Commander, was conducting strategy in all theaters of war, while at the same time, as Commander in Chief of the Army, he was conducting operations in the Eastern theater of war. ${ }^{22}$

Keitel's position under the new arrangement defies an exact definition: technically he was still the Chief of the OKW. But the Armed Forces Leadership Staff of the OKW was no longer used for the Eastern front, where Hitler preferred to deal directly with the General Staff of the Army. Keitel said at Nuremberg that "the Fuehrer dealt knowingly and purposely in two ways: he wanted certain competition concerning the disposition of troops and the distribution of ordnance supplies of all kinds in order to have personal inside knowledge to reach his own final decision." ${ }^{23}$ The Field Marshal was fully aware of the abnormality of this situation and attempted to convince Hitler to appoint a successor to von Brauchitsch; when this was rejected, he attempted another organizational solution which was designed to bring some order and stability into

\footnotetext{
20. Adolf Heusinger, Befehl im Widerstreit: Schicksalsstunden der deutschen Armee, 1923-1945 (Tuebingen: Rainer Wunderlich Verlag Hermann Leins, 1957), p. 155.

21. Warlimont, Inside Hitler's Headquarters, p. 216.

22. Statement by Keitel "The Position and Powers of the Chief of the OKW" on October 9, 1945, Nazi Consptracy and Aggression, VIII, 676.

23. Ibid.
} 
the confused situation. It, too, was rejected by Hitler without an explanation. ${ }^{24}$

It appears that after December 19, 1941, Keitel was completely removed from strategic and operative tasks, an area in which Jodl became more and more Hitler's sole adviser. ${ }^{25}$ Although he attended the daily situation conferences with Hitler, Jodl, the Chief of the General Staff of the Army, and other guests, Keitel's role there, as can be seen from the records of the conferences, consisted mainly in asking questions to clarify minor points or in supplying details of information on administrative and logistical problems. ${ }^{26} \mathrm{He}$ no longer had any influence on appointments to positions in the Wehrmacht: this role had been taken over by Lieutenant General Rudolf Schmundt. ${ }^{27}$ In this "mixture of cloister and concentration camp," ${ }^{28}$ the "Fuehrer Head Quarters," Keitel played his part as Hitler's "lightning rod" 29 and military secretary. But nothing indicates that his devotion to his duty or his loyalty to the Supreme Commander was affected by his humiliating position. On the contrary, as Hitler's suspicion of the generals increased and as his military fortunes declined, Keitel reassured him of his loyalty and continued to defend his decisions against criticism from outsiders. ${ }^{30}$

The increasing influence of National Socialist ideology on the nature of the war became apparent with a Fuehrer Decree of March 1, 1942, addressed to all departments of the Party, the State, and the Armed Forces. In it, Jews, Freemasons, "and their allies" were referred to as the cause of the present war and therefore, so the decree reads, "the systematic spiritual battle against these forces is a task necessitated by the war." Reichsleiter Alfred Rosenberg was entrusted to conduct investigations of confiscated materials from lodges, synagogues, and Jewish archives with the consent of the Chief of the OKW. ${ }^{31}$

In June, 1942, Keitel issued a letter in which he announced that

24. Manuscript by Keitel, "Stellung und Befugnisse des Chefs OKW," on August 15, 1945 (Nelte File), Goerlitz, Keitel, pp. 317-322.

25. Percy Ernst Schramm, Hitler als militaerischer Fuehrer: Erkenntnisse und Erfahrungen aus dem Kriegstagebuch des Oberkommandos der Wehrmacht (2d ed. rev.; Frankfurt am Main: Athenaeum Verlag, 1965), p. 175.

26. Helmut Heiber (ed.), Lagebesprechungen im Fuehrerhauptquartier: Protokollfragmente aus Hitlers militaerischen Konferenzen 1942-1945 (Muenchen: Deutscher Taschenbuch Verlag G. m. b. H. \& Co. KG, 1963), passim.

27. Schramm, Hitler als militaerischer Fuehrer, p. 176.

28. Testimony by Jodl on June 3, 1946, IMT, XV, 295.

29. Affidavit by Hermann Goering on February 14, 1946, (Nelte File), Goerlitz, Keitel, p. 271, n. 89.

30. Bor, Gespraeche mit Halder, p. 23; Major General Bernhard von Lossberg quoted in Goerlitz, Keitel, p. 288, n. 144; Affidavit by Hermann Goering on February 14, 1946 (Nelte File), ibid., p. 271, n. 89.

31. Fuehrererlass of March 1, 1942, cited in Walther Hofer (ed.), Der Nationalsozialismus: Dokumente 1933-1945 (Frankfurt am Main: Fischer Buecherei KG 1957), p. 248 . 
Hitler had informed him that it was now necessary to bring about "unconditional agreement in ideological matters" between the head of state and the Officer Corps. Keitel wrote that he hoped to bring the Officer Corps closer to its Supreme Commander and that, by doing so, to strengthen the belief in the final victory and the will to persevere. ${ }^{32}$ Barely six weeks later, the High Command of the Army issued an order, again over Keitel's signature, which provided for the appointment of officers in charge of Wehrgeistige Fuehrung. ${ }^{33}$

How effective these officers were in influencing the troops is difficult to determine. It seems though that the call for increased political schooling found a favorable response with some troop commanders. The Commanding General of the XIX Army Corps, General Ferdinand Schoerner, issued a special order on February 1, 1943, on his own initiative, which was then distributed by the High Command of the Army to all divisional commanders as a good example of the new type of leadership. ${ }^{34}$ General Schoerner stated in this order that each officer under his command must establish close relations with his men and that he must impress upon the soldiers that the war against the USSR was an ideological war in which there were only two alternatives, "total victory or death." "It is obvious," he wrote, "that the war cannot be won with the discipline of the old army alone. The soldier of to-day wins with his weapons and his Weltanschauung." The nature of the previous political instruction-at least in Schoerner's view-can be gathered from his comment: "I absolutely forbid in the future the cheap kind of lecture in prayer-mill style. . . . I forbid these intellectual and high sounding lectures during which one soldier gets his sound sleep and another one just sits there and looks stupid." 35

It seems doubtful that General Schoerner's example was followed by many troop commanders. In December, 1943, OKW again had to be told to increase the political education of the troops and to cooperate with the Party Chancellery: Hitler ordered the creation of a National Socialist Leadership Staff (NSF Staff) within the OKW and stated that "the Chief of the NSF Staff acts in the execution of his office under my immediate command. He will work in agreement with the NSDAP as the carrier of the political

32. Letter by Keitel to the Commander of the Armed Forces of June 1, 1942, in Waldemar Besson (ed.), "Dokumentation: Zur Geschichte des Nationalsozialistischen Fuehrungsoffiziers (NSFO)," Vierteljahreshefte fuer Zeitgeschichte, IX (January, 1961), 84. 33. Order by High Command of the Army of July 15, 1942, ibid., pp. 84-85. The term wehrgeistige Fuehrung literally means "leadership in the spirit of national defense." It was used in the beginning stages of the program as a euphemism for the training of political fanatics.

34. Ibid., p. 78.

35. Special Order by the Commanding General of the XIX Army Corps of February 1, 1941, ibid., pp. 87-89. 
will." 36 This decree represents the final attempt to make the Wehrmacht a National Socialist instrument of power. The mere fact that it was necessary to create such an institution seems to indicate that National Socialist ideas had not gained the kind of foothold within the Armed Forces which was deemed necessary by the Party.

In a report of December 20,1944, Hauptbereichsleiter ${ }^{37}$ Willy Ruder stated that 1074 National Socialist Leadership Officers (NSF Officers) were employed on a full-time basis and 57,552 on a parttime basis. He also admitted that of the sixty-one General Staff officers who had participated in special NSF training schools not one was deemed suitable for future employment as an NSF Officer. Ruder complained about their distinterested attitude and attributed this to their traditionally Prussian outlook. ${ }^{38}$ Hitler himself took an active part in the re-education program at his own headquarters: in a speech at the end of January, 1944, he encouraged his senior officers to follow his leadership with greater determination as the situation got worse. The response among the officers in Hitler's environment to the NSF Program seems to have been mixed. For example, General Warlimont wrote: "In HQ Area 2 we contrived to avoid being subjected to this Party supervisory system in military clothing, which significantly did not work through the "normal channels.' When the NSFO Headquarters asked us to accept an NSFO Officer, the Staff Adjudant, who was a war-disabled colonel replied: 'we've got no time here for such nonsense." 39

Keitel's involvement in the planning and execution of the NSF Program was only marginal: he received the necessary orders and transmitted them. When on January 7, 1944, General Hermann Reinecke was appointed Chief of the NSF Staff in the OKW, Hitler, Reichsleiter Martin Bormann, Keitel, and several other officers participated in a conference in which Reinecke explained his plans for the implementation of the Fuehrer Decree of December 22, 1943. At one occasion during that conference Keitel attempted to dispel Hitler's fear that the NSF Officers might run into resistance from the rank and file. When he attempted to make a suggestion as to the appointment of an Army representative within the NSF Staff, Hitler quickly suggested General Schoerner because he was a "fanatic." Keitel agreed, saying that such a position should indeed be held by a

36. Fuehrer Decree of December 22, 1943, ibid., p. 94.

37. The title Hauptbcreichsleiter is a Party rank. It is equivalent to the rank of section chief within the Party Chancellery.

38. Draft of report "I Jahr nationalsozialistische Fuehrungsarbeit in der Wehrmacht," by Willy Ruder of December 20, 1944, Besson, "Dokumentation," p. 8I, n. 7.

39. Warlimont, Inside Hitler's Headquarters, p. 420. 
fanatic who could "fire up the men who are not doing their job." 40 The entire NSF Officer Program was significant in a number of respects. It indicated that as late as 1944-1945 the Party had serious doubts about the National Socialist attitude of the Armed Forces. The fact that the NSF Leadership Staff in the OKW was directly responsible to Hitler and Reichsleiter Bormann and not to Keitel as Chief of the OKW indicates that Hitler must have had doubts about the OKW's willingness to carry out such a program. The NSF Officer Program seems to have been dictated to a great degree by the desperate military situation, although the leadership of the program rejected such a notion. ${ }^{41}$ But the timing of the program and the concentration of the appeal on the troops indicate that the overall objective was to instill in the troops a fanatical will to resist the enemy and to hold the line. Wofuer Kaempfen Wir?, a book especially approved by Hitler for the purpose of training officers and men in the National Socialist spirit, provided an example. It contained, of course, the ideological windowdressing: the Reich is a voelkische unit, the Germanic tribes had a heroic history, the Lebensraum theme is of greatest importance, and the historic mission of National Socialism is to create a society for all those of Germanic blood. But the essence of the book was its appeal to loyalty and steadfastness in the face of the enemy: "We know that the most fanatic enemy falters on an even more fanatic adversary. Neither the numbers nor the moral strength of the enemy are inexhaustible. . . . Faith, loyalty, and an iron will . . . will give our weapons the victory." 42 The appeal made in this work was essentially an appeal to the soldierly virtues, to unconditional obedience and loyalty; the ideological element played only a secondary role.

In an order of August, 1944, General Reinecke stressed this point even more: "Considering the present situation, I must point out that it is not the task of the NSF Officer to provide political education. He must instead concentrate on instilling fanaticism in the troops." ${ }^{43}$ This attitude had, in fact, already been voiced by Ruder as early as April, 1944, when he quoted Hitler as saying that he [Hitler] demanded that his officers be not "only" loyal to the Party

40. Record of Fuehrer Conference with General Reinecke, Martin Bormann, Keitel et al., on January 7, 1944, in Gerhard L. Weinberg (ed.), "Dokumentation: Adolf Hitler und der NS-Fuehrungsoffizier (NSFO)," Vierteliahreshefte fuer Zeitgeschichte, XII (October, 1964), 446-456.

41. Letter by the Commander of the Relief Army on May 14, 1943, Besson, "Dokumentation," p. 90.

42. Wofuer Kaempfen Wir? cited in Dr. Hans-Adolf Jacobsen and Dr. Werner Jochmann (eds.), Ausgewaehlte Dokumente zur Geschichte des Nationalsozialismus 1933-1945 (Bielefeld: Neue Gesellschaft G. m. b. H., 1961), n. p.

43. Letter from General Reinecke of August 3, 1944, Besson "Dokumentation," p. 113. 
and its goals but that the officers must be the "most fanatic representatives of the National Socialist State." 44

Although it is not possible to measure in any significant way the actual influence of the NSF Program on the Armed Forces, the increasing emphasis on loyalty and obedience in the appeals of the NSF Staff during the end of 1944 and the beginning of 1945 seems to indicate that ideological training as a means to instill fanaticism was by and large a failure. Barely a month before the collapse of the Third Reich, a party official who had a chance to observe the effects of the NSF Program wrote to his superior about the lack of conviction in the ranks even of the NSF Officers. He appealed to his superior to see to it that the control of the program be removed from the Fuehrer Head Quarters and given directly to Reichsleiter Bormann: "Only the Party can now force a decision," he thought. ${ }^{45}$

44. Speech by Willy Ruder to high ranking party functionaries on February 23, 1944, in Munich, ibid., p. 106.

45. Memorandum to Hauptamtsleiter Heinrich Walkenhorst from Pg. Buergel of April 4, 1945, ibid., p. 116. 



\section{Chapter VI}

\section{Conclusion}

The rise of National Socialism as an all-embracing philosophy of life constituted perhaps the most far-reaching impact on recent German history. It swept into power an unknown Austrian corporal and enabled him to become the unlimited dictator of Europe within a few years. In Germany the National Socialist revolution with its avowed goal of Gleichschaltung affected every aspect of life and every institution of society. Even the German Army, traditionally a power in itself, was unable to keep aloof from the revolutionary dynamics of the National Socialist movement.

Although the Reichswehr of the Weimar Republic attempted to play the traditional role of a state within the state by attempting to stay above politics, the promises of Adolf Hitler to restore the Army to its former position of power struck a responsive chord in the Corps of Officers. His pseudo-military bearing and language, his hatred of the Social Democratic "system," and his ability to arouse enthusiasm in an apathetic Corps of Officers made the Reichswehr leaders forget, that once started, a revolution of this kind would not stop at the barracks' gates. Their political ignorance, fostered by their traditional distaste for anything political, proved to be an invaluable asset for a manipulator of Hitler's skills. The Fuehrer went to great lengths to prove his good will towards the Army. When he eliminated Ernst Roehm and his SA, Hitler fulfilled the Army's greatest desire: to be once again the only arms bearer in the Reich.

But Hitler's gift to the military leaders proved to be a Trojan horse. The independence of the Reichswehr was threatened when the 100,000 man army was flooded with conscripts of a new generation who carried the seeds of the revolution into the once tightly controlled Reichswehr. A second attack on the "state within the state" came from another direction. Scandals and trumped-up charges as well as outright murder removed a number of leading personalities within the Reichswehr until the conditions were ripe for Hitler's second move: the assumption of direct command over the Armed Forces on February 4, 1938. With this political masterstroke the High Command of the Armed Forces was quietly changed from an agency with relative independence from politics into a tool 
for Hitler, the politician. Wilhelm Keitel, an efficient bureaucrat, who, like most of his fellow officers, did not comprehend that he was participating in a revolution, was elevated to the post of Chief of the High Command. Although the Party boasted of having created a National Socialist Wehrmacht, neither Keitel nor most of the generals were National Socialists. The key factor in Hitler's gaining direct control of the Armed Forces was his skillful manipulation of power and his uncanny sense of timing rather than his ability to sway the generals to a National Socialist point of view.

"Nothing convinces the soldier as quickly as success," Keitel once said. ${ }^{1}$ The military successes in Poland and France undoubtedly served well to establish the Army's confidence in its self-appointed leader and Supreme Commander. The military conflict with the Soviet Union demanded, however, not only that the Army have confidence in Hitler's military leadership but that it identify with the ideological causes of this war: the extermination of the socalled "biological basis of Bolshevism." Hitler realized that the ideological commitment of his generals and of the Army as a whole was sadly lacking. The resignation of General von Brauchitsch in 1941 seemed to provide an answer to this problem. Rather than appoint a successor Hitler repeated his performance of February 4, 1938, and personally took command of the Armies in the East to educate the troops in the National Socialist spirit. The High Command of the Armed Forces was reduced to playing the part of a military secretariat with drastically curtailed responsibilities.

The Chief of the OKW, whose functions now seemed to be dictated mostly by Hitler's needs, rather than the Army's, became a pathetic figure: disliked by most field commanders and humiliated by Hitler, he was yet unable to free himself from his traditional concepts of honor and duty. "Loyalty is the core of honor" 2 had been his motto throughout his military career; he was proud of having been Hitler's "faithful shieldbearer." 3 Keitel attempted to reconcile his participation in criminal and unsoldierly acts with his code of honor by pointing to his sworn duty to unquestioning obedience. Whether he ever reconciled these acts with his conscience could not be determined.

Hitler's attempt to educate the Army in the spirit of National Socialism must be called a failure. The last minute NSFO Program was an admittance that the majority of the Army had not committed

1. Walter Goerlitz (ed.), Generalfeldmarschall Keitel: Verbrecher oder Offizier? Erinnerungen, Briefe, Dokumente des Chefs OKW (Goettingen: Musterschmidt Verlag, 1961), p. 406.

2. Ibid., p. 434.

3. Ibid., p. 405. 
itself to the ideology of the Party. The failure of the NSFO Program was demonstrated by the fact that its appeals fell largely on deaf ears. With the worsening military situation in 1944, the ideological element in the program was gradually replaced by attempts to instill a kind of nihilistic fanaticism in the troops. As for Keitel, he appears rather as the prototype of the unpolitical military professional who, steeped in the concepts of another age, found himself involved in issues outside his field of specialization. Like most other military leaders he continued to do his job and ignored the moral issues involved in being "the devil's general," because there was no one to tell him how to resolve them. Hitler's attempt to create a National Socialist Army through a slowly evolving program of political indoctrination beginning in 1933 was a failure. Although the pressures of the Eastern campaign brought in their wake an intensification of Party influence, the Army remained essentially unchanged. 
. 


\section{BIBLIOGRAPHY}

\section{Primary Works}

\section{BOOKS}

\section{A. Published Official Documents}

Besson, Waldemar, ed. "Dokumentation: Zur Geschichte des Nationalsozialistischen Fuehrungsoffiziers (NSFO)." Vierteljahreshefte fuer Zeitgeschichte, IX (January, 1961), 77-115.

This documentation contains the most important letters and directives dealing with the development of the NSF Officer Program.

Heiber, Helmut, ed. Lagebesprechungen im Fuehrerhauptquartier: Protokollfragmente aus Hitlers militaerischen Konferenzen 1942-1945. Muenchen: Deutscher Taschenbuch Verlag G. m. b. H. \& Co. KG, 1963.

This work contains selected records of Hitler's military conferences from December 1, 1942, to March 23, 1945. The volume provides a good picture of Hitler's influence on the conduct of military operations during that period.

Hofer, Walther, ed. Der Nationalsozialismus: Dokumente 1933-1945. Frankfurt am Main: Fischer Buecherei K. G., 1957.

The editor collected various documents on the most significant aspects of National Socialism. The basis for selecting the documents was the editor's attempt to provide a comprehensive picture of National Socialism through its most important documents.

International Military Tribunal. Trial of the Major War Criminals Before the International Military Tribunal. 42 vols. Nuremberg: International Military Tribunal, 1949.

These volumes represent by far the most extensive collection of documents on the major figures of the Third Reich. Volumes I-XXII record the proceedings in the course of the trial; volumes XXV to XLII contain documents in evidence presented by both the prosecution and the defense.

Office of the United States Chief Counsel for Prosecution of Axis Criminality. Nazi Conspiracy and Aggression. 8 vols. and 2 supplementary vols. A and B. Washington: U. S. Government Printing Office, 1946.

These volumes contain translations of most of the documents used by the Prosecution Counsels of the United States and the United Kingdom. They also contain certain defense documents as well as affidavits and texts of interrogations by representatives of the prosecution. Because of the obvious emphasis on the work of the prosecution, these volumes should be used only in connection with less weighted documents.

Trevor-Roper, H. R., ed. Blitzkrieg to Defeat: Hitler's War Directives 19391945. New York: Holt, Rinehart and Winston, 1965.

This volume contains the text of Hitler's war directives from the attack on Poland to the end of the war. It is an adaptation of Walter Hubatsch, ed. Hitlers Weisungen fuer die Kriegfuehrung 1939-1945, Dokumente des Oberkommandos der Wehrmacht. Frankfurt am Main: Bernard \& Graefe Verlag fuer Wehrwesen, 1964.

Weinberg, Gerhard L., ed. "Dokumentation: Adolf Hitler und der NSFuehrungsoffizier (NSFO)," Vierteljahreshefte fuer Zeitgeschichte, XII (October, 1964), 443-456.

This documentation contains the complete record of the Fuehrer conference with General Reinecke on January 7, 1944. 


\section{B. Speeches}

Domarus, Max, ed. Hitler: Reden und Proklamationen 1932-1945. 2 vols. Muenchen: Sueddeutscher Verlag, 1965.

These two volumes contain the greater part of Hitler's speeches and proclamations between 1938 and 1945. The editor arranged the speeches in chronological order and provided a running commentary on Hitler's day by day activities. Also included are the texts of numerous telegrams, letters, orders, and newspaper articles as well as several excerpts from various diaries.

C. Memoirs

Goerlitz, Walter, ed. Generalfeldmarschall Keitel: Verbrecher oder Offizier? Erinnerungen, Briefe, Dokumente des Chefs OKW. Goettingen: Musterschmidt Verlag, 1961.

The editor of this work was given permission by Keitel's son to use all of the Field Marshal's papers for the preparation of this volume. The major part of the work consists of Keitel's memoirs. The first part of these covers the period from 1933 to 1938 and was completed at Nuremberg in September of 1946. The second part of the memoirs deals with the period from 1938 to the battle of Stalingrad and was completed on September 29, 1946. Due to the pressures of time (Keitel was executed on October 16, 1946) the memoirs could not be completed. The Field Marshal found time only to write one brief paper on the last days of the war as well as several letters, all of which are contained in this volume.

This work also contains Keitel's family correspondence, several official documents, memoranda, and other notes by Keitel dealing primarily with problems of army organization. Various communications between Keitel and his defense counsel on topics of importance to the conduct of the defense during the Trial of the Major War Criminals at Nuremberg are contained in this volume and contributed greatly to this manuscript.

Heusinger, Adolf. Befehl im Widerstreit: Schicksalsstunden der deutschen Armee, 1923-1945. Tuebingen: Rainer Wunderlich Verlag Hermann Leins, 1957.

This work was of great help in understanding the situation at the OKW after Hitler took command of the Army in 1941.

Hossbach, Friedrich. Zwischen Wehrmacht und Hitler 1934-1938. 2d ed. revised. Goettingen: Vandenhoeck \& Ruprecht, 1965.

General Hossbach's Memoirs are of special importance for the period from 1934 to 1938. His position as "Adjutant of the Wehrmacht with the Fuehrer" and his simultaneous employment with the General Staff enabled him to gain valuable insights into the Fuehrer's methods of dealing with the Army.

Papen, Franz von. Memoirs. Translated by Brian Connell. London: Andre Deutsch, 1952.

This work contains a good description of the Berghof conference between Hitler and Schuschnigg.

Rauschning, Hermann. Hitler Speaks: A Series of Political Conversations with Adolf Hitler on his Real Aims. London: Thornton and Butterworth Ltd., 1940.

This work was of great value in assessing Hitler's views before he became Chancellor.

Schlabrendorff, Fabian von. Offiziere gegen Hitler. Frankfurt am Main: Fischer Buecherei, KG., 1962.

This work contains a good analysis of the role of the German officer during the Third Reich.

Warlimont, Walter. Inside Hitler's Headquarters 1939-1945. Translated by R. H. Barry. New York: Frederick A. Praeger, Publishers, 1965. 
This work by the former Chief of National Defense Section of the OKW is especially valuable as a source for the actual working of the OKW. It contains detailed information on the role of the OKW in the various theaters of war as well as fragments of conference records in the Fuehrer Headquarters.

D. Others

Bor, Peter. Gespraeche mit Halder. Wiesbaden: Limes Verlag, 1950.

Hitler, Adolf. Mein Kampf. Muenchen: Zentralverlag der NSDAP., Franz Eher Nachf., 1944.

Jacobsen, Dr. Hans-Adolf and Jochmann, Dr. Werner, eds. Ausgewaehlte Dokumente zur Geschichte des Nationalsozialismus 1933-1945. Bielefeld: Neue Gesellschaft G. m. b. H., 1961.

Rauschning, Hermann. The Revolution of Nihilism: Waming to the West. New York: Alliance Book Corporation, 1939.

II. SECONDARY Works

\section{BOOKS}

Buchheim, Hans, Broszat, Martin, Jacobsen, Hans-Adolf and Krausnick, Helmut. Anatomie des SS-Staates. 2 vols. Olten and Freiburg im Breisgau: Walter Verlag, 1965.

Bullock, Alan. Hitler: A Study in Tyranny. Compl. rev. ed. New York: Harper \& Row, Publishers, 1962.

Clark, Alan. Barbarossa: The Russian German Conflict, 1941-1945. New York: William Morrow and Company, 1965.

Craig, Gordon A. The Politics of the Prussian Army 1640-1945. New York: Oxford University Press, 1964.

Davidson, Eugene. The Trial of the Germans: An Account of the twenty-two defendants before the International Military Tribunal at Nuremberg. New York: The Macmillan Company, 1966.

Delarue, Jacques. The Gestapo: A History of Horror. Translated by Mervyn Savill. New York: Dell Publishing Co., Inc., 1965.

Demeter, Karl. Das Deutsche Offizierskorps in Gesellschaft und Staat 16501945. 4th ed. Revised and expanded. Frankfurt am Main: Bernard \& Graefe Verlag fuer Wehrwesen, 1965.

Foertsch, Hermann. Schuld und Verhaengnis: Die Fritsch-Krise im Fruehjahr 1938 als Wendepunkt in der Geschichte der nationalsozialistischen Zeit. Stuttgart: Deutsche Verlagsanstalt, 1951.

Freund, Michael. Deutschland unterm Hakenkreuz: Die Geschichte der Jahre 1933-1945. Guetersloh: C. Bertelsmann Verlag, 1965.

Gilbert, G. M. Nuremberg Diary. New York: The New American Library of World Literature, Inc., 1961.

Heiden, Konrad. Der Fuehrer: Hitler's Rise to Power. Translated by Ralph Manheim. Boston: Houghton Mifflin Co., 1944.

Hillgruber, Andreas. Hitlers Strategie: Politik und Kriegfuehrung 1940-1941. Frankfurt am Main: Bernard \& Graefe Verlag fuer Wehrwesen, 1965.

Kelley, Douglas M., M. D. 22 Cells in Nuremberg. New York: McFadden Publications, Inc., 1961.

Liddell, Hart, B. H. The German Generals Talk. New York: William Morrow \& Co., 1948. 
Mau, Hermann and Krausnick, Helmut. Deutsche Geschichte der iuengsten Vergangenheit 1933-1945. Tuebingen: Rainer Wunderlich Verlag Hermann Leins and Stuttgart: J. B. Metzlersche Verlagsbuchhandlung, 1964.

O'Neill, Robert J. The German Army and the Nazi Party, 1933-1939. New York: James H. Heineman, Inc., 1966.

Rosinski, Herbert. The German Army. Edited and with introduction by Gordon A. Craig. New York: Frederick A. Praeger, Publishers, 1966.

Schoenbaum, David. Hitler's Social Revolution: Class and Status in Nazi Germany 1933-1939. Garden City, N. Y.: Doubleday \& Company, Inc., 1967.

Schramm, Percy Ernst. Hitler als militaerischer Fuehrer: Erkenntnisse und Erfahrungen aus dem Kriegstagebuch des Oberkommandos der Wehrmacht. 2d ed. revised. Frankfurt am Main: Athenaeum Verlag, 1965.

Schueddekopf, Dr. Otto Ernst. Das Heer und die Republik: Quellen zur Politik der Reichswehrfuehrung 1918-1933. Hannover: Norddeutsche Verlagsanstalt O. Goedel, 1955.

Taylor, Telford. The March of Conquest: The German Victories in Western Europe, 1940. New York: Simon and Schuster, 1958.

Trevor-Roper, H. R. The Last Days of Hitler. New York: The Macmillan Co., 1947.

Waite, Robert G. Vanguard of Nazism: The Free Corps Movement in Post War Germany 1918-1923. Cambridge, Mass.: Harvard University Press, 1952.

Westphal, Siegfried. The German Army in the West. London: Cassell and Company, Ltd., 1951.

Wheeler-Bennett, John W. The Nemesis of Power: The German Army in Politics 1918-1945. 2d ed. London: Macmillan \& Co., Ltd., 1964.

\section{ARTICLES}

Assmann, Vice Admiral, Kurt. "Hitler and the German Officer Corps." Translated by Captain Roland E. Krause, United States Naval Institute. Proceedings, LXXX (May, 1956), 509-520.

Goerlitz, Walter. "Wallensteins Lager 1920-1938: Das Verhaeltnis der deutschen Generalitaet zur Republik und zum Nationalsozialismus." Frankfurter Hefte, No. 5 (May, 1948), pp. 414-424. 
PRINTED BY
ROBERT R. (BOB) SANDERS, STATE PRIMTER TOPEKA, KANSAS

1970

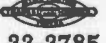



Literature Series

(Contimued from tnide frant cover)

No, 4. Mrs. Undarwood: Livigint, Litinteuve, by Carol Waxd Craine. Jane 1965

Musie Series

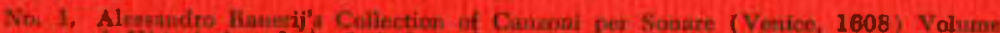
I Historicat and Analytical Stuity, by Lelind Kat Bartholotoeye. Decrmber 1965

Music Suties

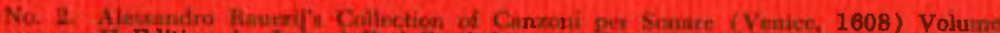
I1 Edition, by Leland Earl Bartieloraew, Decentiber 16es.

$1068-1967$

Sulence Series

No, 5 Ecotopocal stutien of Blue Grame Grass. Iy Frod W. Albertson, David A Bicast, and Cerald W, Tomanek, Noventoer $106 \theta$.

Art Series

No. 2. An Apprinach to Cradioate stady, by John C. Thoma, Jr. December 1966.

\section{Scienco Series}

Na 6. Mammalint Distribution Witbin Bictio Communitier of Northeastern Ievell County. Kiruns, by Kennith W. Antersm and Eusene D. Fleharty. March 1967.

\section{Literature Series}

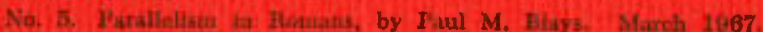

Bibliogrephy Series

\section{$1967-1968$}

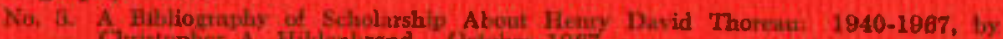
Cirrstupher A: Hilde al rand Uctobei $19 \mathrm{kF}$.

\section{Science Series}

No. 7. Seif-Vegtation Reintionships of Blite Shale-Limy Upland Range Sito in Eli. Coruty, Xantas, by Litry D. Zwreaky. December 1067.

\section{Science Series}

No. 8. Invertebrate Fauna and Eavironinent of Deposition of the Niobran Formation (Cretacebuf) of Kansas, by Halsey W. Mullex, March 1968.

\section{Histary Series}

No, 4. Kaniss Misinovaites During World War L by Arlya John Turah. May 1968.

\section{History Series}

\section{$1968-1969$}

No. 5. . C. Deroun Public Seryant and State Primpter of Southweters Kansas, by Larny N, Lane. October 1968

\section{Literature Serties}

No. 8. A Comparative Anibysis of the Rhetoric af Two Nezo W/omen Orator

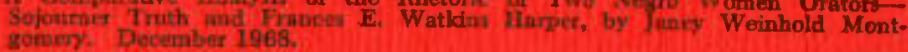

\section{Music Serles}

No. 3. A Histary of the Violti Etude to About 1800 (Volume 2), by K Marie Stolba December 1968

$$
1969-1970
$$

\section{Music Series}

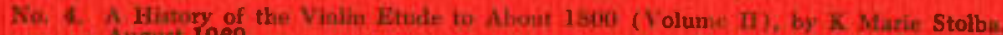
Angust 1969 .

Ifistory Series:

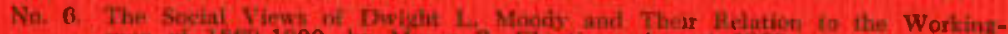
mua of $3860-1000$ by My ron R. Chartiet. Autout 1960 

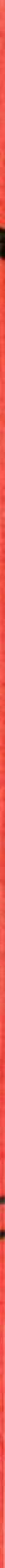